\title{
The Afterlives of Bede's Tribal Names in English Place-Names
}

\author{
John Baker and Jayne Carroll
}

Bede famously traced the origins of the Anglo-Saxons back to three of the strongest Germanic “tribes”:

They came from three very powerful Germanic tribes [de tribus Germaniae populis fortioribus], the Saxons [Saxonibus], Angles [Anglis], and Jutes [Iutis]. The people of Kent and the inhabitants of the Isle of Wight are of Jutish origin and also those opposite the Isle of Wight, that part of the kingdom of Wessex which is still today called the nation of the Jutes. From the Saxon country, that is, the district now known as Old Saxony, came the East Saxons, the South Saxons, and the West Saxons. Besides this, from the country of the Angles, that is the land between the kingdoms of the Jutes and the Saxons, which is called Angulus, came the East Angles, the Middle Angles, the Mercians, and all the Northumbrian race (that is those people who dwell north of the river Humber) as well as the other Anglian tribes. ${ }^{1}$

Already in the time of Bede, it is clear that these three people-names could be used to denote both continental and insular peoples. Indeed, in Old English (OE) texts, Engle 'Angle' is used in several ways: (1) to refer to the inhabitants of Angeln; (2) to refer to one of the constituent bodies of the Germanic-speaking inhabitants who arrived in lowland Britain, and who settled, traditionally at least (as in Bede's Historia), in midland and northern areas of what was to become England, and in contrast to Saxons and Jutes (and others); ${ }^{3}$ (3) the

1 Bede, $H E$ I.15.

2 Thus, for example, the narrator of Widsith records that Engle and Swafe observe the border established by Anglian king Offa; the narrator himself depicts himself mid Englum "among Angles” (George Philip Krapp and Elliott Van Kirk Dobbie, eds., The Exeter Book, The AngloSaxon Poetic Records 3 (New York, 1936), pp. 154-56, line 61).

3 The Battle of Brunanburh recalls the adventus Saxonum, sippan eastan hider Engle ond Seaxe ... Brytene sohtan 'when hither from the east Angles and Saxons sought Britain' (1l. 69-71); The Battle of Brunanburh, ed. Alistair Campbell (London, 1938). 
Germanic-speaking inhabitants of England without explicit distinction between Angles, Saxons, and Jutes, as in the compound Engla-lond 'England'. This last sense is the one found most frequently in $\mathrm{OE}$ texts, and was well established by the late 9th to early 1oth century. OE Seaxe 'Saxons' shadows Engle's first two senses, denoting: (1) the Old Saxons on the continent; (2) the Saxons in England. ${ }^{4}$ In Old English, unlike Engle, it does not seem to have developed the more general sense 'English people', although that is the main application of its cognate in the Brittonic languages (see e.g. Welsh Saison, Cornish Zowzon). ${ }^{5}$

These two people-names are well attested in Old English sources. The same cannot be said of the Jutes, who appear only infrequently in Anglo-Saxon texts. They are one of the Continental peoples named in Widsith (Ytum), ruled by the otherwise unknown Gefwulf. ${ }^{6}$ In the Anglo-Saxon Chronicle's version of Bede's account, the Jutes are Iotum or Iutum (dative plural) and Iutna cyn ('people of the Jutes'), ${ }^{7}$ but in the Old English translation of Bede's Ecclesiastical History, Latin Iutis is rendered as Geatas 'Geats' (the Scandinavian people to whom Beowulf was said to belong) rather than Ëote 'Jutes', although Iutorum provincia is given, correctly, as Eota land. ${ }^{8}$ The Middle English Dictionary notes use of Iutes, Jutys, but only from the late 14th century onwards and confined to historical passages following the Bedan tradition. What little evidence there is suggests very limited use of the word E Ete and confusion about the identity of the peoples called, in Latin, Iuti. It appears that the word fell out of general use early on and was preserved principally in works drawing from Bede's account.

Nevertheless, all three of these people-names are thought to have given rise to place-names in England, although in intriguingly different proportions, as will become evident below. Englar and Saksar, the Old Norse cognates of Engle and Seaxe, are also thought to appear in names in those areas of England

4 An Anglo-Saxon Dictionary, Based on the Manuscript Collections of the Late Joseph Bosworth, 1st ed. (Oxford, 1898) and Supplement, 1st ed. (Oxford, 1921), ed. Joseph Bosworth and T. Northcote Toller. Note in the late gth century, for instance, the Anglo-Saxon Chronicle's $\partial a$ Seaxan hoefdun sige 'there the [Old] Saxons had the victory' (ASC s.a. 885).

5 See sais in Geiriadur Prifysgol Cymru online, <http://welsh-dictionary.ac.uk/gpc/gpc.html>; O.J. Padel, Cornish Place-Name Elements (Nottingham, 1985), p. 210.

6 Widsith, 1. 26.

7 ASC A, s.a. 449. This is rendered as Giota, Giotis in Æthelweard, Chronicon, p. 8.

8 Bede, Ecclesiastical History 4.16; The Old English Version of Bede's Ecclesiastical History of the English People, IV.18, ed. Thomas Miller (London, 1890); Bede's terras Iutorum 'Jutish lands' in the same chapter is omitted from the Old English. See also Bosworth and Toller, Anglo-Saxon Dictionary; William Henry Stevenson, Asser's Life of King Alfred Together with the Annals of Saint Neots Erreoneously Ascribed to Asser (Oxford, 1906; repr. 1956), pp. $166-70$. 
settled by Scandinavians in the later Anglo-Saxon period, or heavily influenced by their language. These Old English and Old Norse names take their place alongside a range of others which have ethnonyms as their specific elements. ${ }^{9}$ The other groups identified in such place-names include Brittonic and Goidelic speakers, early Germanic tribal communities, and communities distinctly Scandinavian or northern European in some way. ${ }^{10}$

Such place-names are traditionally interpreted as denoting isolated groups of ethnically or linguistically distinctive people. ${ }^{11}$ That, common sense tells us, is how they work as names - there is little point describing a place as the village of the Frisians if all of the surrounding villages also contain Frisians. It is usually assumed, too, that the names were given not by the inhabitants of the settlements themselves but by their neighbours, surrounding communities who identified these groups as ethnically or linguistically different, something other than the "norm," whatever that might have been. In some cases, however, self-identification must also have been a factor.

As is already clear in Bede's account, two of the three ethnonyms that are the focus of this paper gave rise to a number of derived people-names, most of which are associated with kingdoms of the middle Anglo-Saxon period. These are the East Saxons (Bede's Orientales Saxones and the Eastseaxan of the OE translation), South Saxons (Meridiani Saxones; Suðseaxan) and West Saxons (Occidui Saxones; Westseaxan); East Angles (Orientales Angli; Eastengle) and Middle Angles (Mediterranei Angli; Middelengle). A further group are the Middle Saxons, named in other sources from the 8th century onwards. ${ }^{12}$ Many of these names survived as the names of shires or regions. In the former category are Essex, Sussex and Middlesex; in the latter are Wessex and East Anglia. It seems that there was at one time a Jutish territory, the Iutarum natio or Iutorum provincia described by Bede, the Eota Land of his Old English translator, Iutna cyn of the Anglo-Saxon Chronicle and (in) provincia Jutarum of the 12th-century Chronicle of John of Worcester. ${ }^{13}$ The name does not seem to have survived as a district name, and the other regions reportedly settled by Jutes do

$9 \quad$ The specific or qualifying element is usually the first element in a construction such as Engleton (Staffordshire), OE Engle 'Angles, English' + OE tūn 'farm, settlement, estate', i.e. 'farm of the Engle'.

$10 \quad$ Eilert Ekwall, "Tribal names in English place-names," Namn och Bygd 41 (1953), 129-77.

11 See, for example, the comments on Dene and Norðmenn names in Kenneth Cameron, English Place Names, new ed. (London 1996), p. 77 .

12 J.E.B. Gover, Allen Mawer and F.M. Stenton, The Place-Names of Middlesex, apart from the City of London (Cambridge, 1942), p. 1.

13 JW vol. 3, s.a. 1099. See Nick Stoodley, "Costume Groups in Hampshire and their Bearing on the Question of Jutish Settlement in the Later $5^{\text {th }}$ and 6th centuries AD," above, p. 88. 
not seem to have been given names commemorating that tradition-the people of Kent are the Cantware, not the ${ }^{*} \bar{E}$ ast $\bar{E}$ ote, those of Wight the Wihtware or Wihtsēte, not the *Sūð Eিote.

These names of kingdoms and regions are not the main focus of this paper, but one appears also in a place-name and one as a charter bound: Exton 'farm, estate or settlement of the East Saxons' (cet east seaxnatune 940 [S 463; 12thcent. MS]; Hampshire, O.S. SU 614211); ${ }^{14}$ and supsaxa lond 'land belonging to the South Saxons' (c.848 [S 1193; 13th-cent. MS]; near Burmarsh, Kent; O.S. TR 105315). $\cdot^{15}$ They are therefore worth brief mention. J.K. Wallenberg points out that the latter is on the eastern boundary of the estate being described, and may therefore refer to a detached area of land belonging to the South Saxons. ${ }^{16}$ These seem to be comparable with place-names such as Markfield (Leicestershire; Merchenefeld in Domesday Book [1086]) and Markingfield (West Yorkshire; Merchefeld 1086, Merkenfeld in the Lay Subsidy Roll of 1297), both of which can be interpreted as 'open land of the Mercians',17 Conderton (Worcestershire; Cantuaretun 875 [S 216; 11th-cent. MS]) and Canterton (Hampshire; Cantortun 1086), 'farm or settlement of the people of Kent', 18 and Wychwood (Oxfordshire; Huiccewudu 841 [S 196; 11th-cent. MS]), which is 'woodland of the Hwicce. ${ }^{19}$ Such place-names commemorate an association with a particular kingdom or shire.

The purpose of this chapter is to examine English place-names containing the (ostensibly) less specific group-names Engle/Englar, Seaxe/Saksar, and $\bar{E}$ ote, assessing the material and noting the difficulties involved, in some cases, in securely identifying reliable examples. It then examines the significance of the survival of Angles, Saxons and Jutes in English toponymy, and considers the range of possible identities reflected in the place-names: did such names reflect identities which in some sense date back to the time of the Anglo-Saxon settlements, later perceptions of such identities, or a separate assertion of ethnic identity in the middle or later Anglo-Saxon periods? What might it have

14 Allen Mawer, Place-Names and History (Liverpool and London, 1922), p. 10; Richard Coates, The Place-Names of Hampshire (London, 1989), p. 74; CDEPN, p. 222.

15 Paul Cullen, "The Place-Names of the Lathes of St Augustine and Shipway, Kent," PhD thesis (University of Sussex, 1997), p. 217.

16 J.K. Wallenberg, Kentish Place-Names (Uppsala, 1931), p. 270.

17 Ekwall, "Tribal Names," p. 141; Barrie Cox, The Place-Names of Leicestershire, 7 vols (Nottingham, 1998-2016), part 6, p. 175; A.H. Smith, The Place-Names of the West Riding of Yorkshire, 8 vols (Cambridge, 1961-63), part 5, p. 177 .

18 Mawer, Place-Names and History, p. 10; Ekwall "Tribal Names," p. 133; Smith, Place-Names of the West Riding, part 5, p. 177, part 7, pp. 37, 38; Coates, Place-Names of Hampshire, p. 49.

19 Ekwall "Tribal Names," p. 142; Margaret Gelling, The Place-Names of Oxfordshire (Cambridge, 1953-54), p. 386. 
meant to be described as Engle, Seaxe or Ëote at the point at which these names were meaningful labels? What was the range of functions of names which contained these elements? It should be emphasized that this chapter will focus on the toponymic evidence; for reasons of space, broader questions of the use of these names in literary texts will not be explored in detail.

\section{Establishing a Corpus}

Modern forms of place-names are not a reliable guide to their etymology (the words which made up the names when they came into existence, as meaningful descriptions of places). Place-name scholars collect early attestations of the names - the earlier the better-in order to move back in time, as close as possible to the point of naming (and therefore to transparency in meaning). To take just one example, the modern name Englefield Green, Surrey, looks as though it could well belong to a corpus of Engle-names. All but one of its medieval attestations, though, lack $<\mathrm{l}>$ (e.g. Hingefelda 967 [S 752; 13th-cent. MS], and Ingefeld, recorded in 1291, 1295, 1317, and so on), which suggests that the etymology of the name is more likely to be the Old English personal name Inga + OE feld 'open land': 'Inga's open land' + modern English green. ${ }^{20}$ Only with early spellings therefore, is it possible to suggest a likely etymology for a name. Even with a good record of early attestations, there may be further complications in determining with confidence the words which made up the name at its inception. The discussion below assesses place-names attested before 1400 whose early forms suggest that they could be included in a corpus of Engle-, Seaxe-, and Eote-place-names. Each set of place-names is analysed in turn, with indications given of the level of confidence we have in an individual name's suggested etymology. The intention is to establish a (relatively) reliable corpus of relevant names, which can then form the basis of a discussion of what these ethnonyms may have signified when they were used as place-name elements.

\section{OE Engle or ON Englar}

The identification of names in OE Engle or Old Norse (ON) Englar is relatively straightforward. As the specific (first element) in a place-name, the ethnonym would appear in the genitive plural form, and, for both the Old English and Old

20 J.E.B. Gover, Allen Mawer, and F.M. Stenton, The Place-Names of Surrey (Cambridge, 1934), pp. 120-21; CDEPN, pp. 216-17. The sole medieval spelling with $<\mathrm{l}>$ is Ingelfield (1282); there are seven extant medieval spellings which lack $<\mathrm{l}>$. 
Norse, this is Engla 'of the Engle'.21 Over time, the unstressed genitive inflection $-a$ would have become less distinct $(>/ \partial /)$, with this represented in the written record by Engle-. Neither Engla- nor Engle- is close in form to other place-nameforming elements, and there are no English or Scandinavian personal names with which they might be confused. In other words, early place-name spellings which begin Engla- or Engle- are generally accepted as containing forms of the ethnonym Engle/Englar. It has also been suggested that an uninflected root-form of the ethnonym, Engel, might appear in Engelhamstcede, one of the bounds of Wootton St Lawrence, in Hampshire, ${ }^{22}$ but parallels for such a use of uninflected ethnonyms seem to be confined to names for territories or kingdoms. ${ }^{23} \mathrm{~A}$ singular form of the ethnonym (and possible personal name), Angel, has been suggested as the first element of Anglesey (Cambridgeshire); ${ }^{24}$ it is not, however, independently attested as a personal name in early medieval England and an alternative etymology for this name is more likely. ${ }^{25}$ In what follows each of the Engle-names is listed under its generic (second element), with relevant comparative material.

\section{With OE generics}

OE burna 'stream'

\section{Great Englebourne (Devon; O.S. SX 775565)}

Engleborna 1086, Engleburne 1250

Compare Walburn in the North Riding of Yorkshire, whose first element may be Walh 'Briton'.27

OE feld 'open land'

$$
\text { Englefield (Berkshire; O.S. SU 625725) }{ }^{28}
$$

21 Engle is an $i$-stem, whose 'original' genitive plural would have been Engla; early forms of Ing Lane (see below) may suggest that a (secondary) genitive plural form Englena may have been formed on the model of $n$-stems; Alistair Campbell, Old English Grammar (Oxford, 1959), §610(7); Richard M. Hogg and R.D. Fulk, A Grammar of Old English. Volume 2-Morphology (Chichester, 2011), §2.70.

22 Karl Inge Sandred, English Place-Names in -stead (Uppsala, 1963), p. 275.

23 See also the comments on the possible use of uninflected Seax-for Seaxe below, and the references in n. 46 .

$24 D E P N$, p. 10.

25 P.H. Reaney, The Place-Names of Cambridgeshire and the Isle of Ely (Cambridge, 1943), p. 131.

26 J.E.B. Gover, Allen Mawer, F.M. Stenton, The Place-Names of Devon, 2 vols (Cambridge, 1931-32), pp. 325-26; DEPN, p. 167.

27 A.H. Smith, The Place-Names of the North Riding of Yorkshire (Cambridge, 1928), p. 270.

28 Margaret Gelling, The Place-Names of Berkshire, 3 vols (Cambridge, 1973-76), p. 211; DEPN, p. $167 ; C D E P N$, p. 216. 
(on) Englafelda c. 900, Inglefelle, Englefel 1086, Englefeldia 1154×89 The co-occurrence of OE feld with ethnonyms is notable: compare Merce 'Mercians' in Markfield, Leicestershire, and Markingfield, West Riding of Yorkshire, Daynesfeld in Cheshire (singular Dene 'a Dane', or possible personal name), and the two possible Seaxe examples, below. ${ }^{29}$

\section{OE häm-stede 'homestead'}

\section{Engelhamstcede (Hampshire; O.S. SU 592532) (30 $^{30}$}

(on) Engelhamstcede 990 (S 874; mid-12th-cent. MS)

Karl Inge Sandred suggested that < Ængel $>$ here stands for Engel (note < stæde> for stede), a root form of Engle, and that this name could therefore be interpreted as "the homestead of the Anglians." This root form seems not to occur elsewhere in place-names, nor is $\mathrm{OE}$ häm-stede otherwise found with groupnames, so a question remains as to whether this is indeed an instance of the ethnonym.

\section{OE lane 'lane'}

Ing Lane (now Maiden Lane; London; O.S. TQ 297804) ${ }^{31}$

Englenelane 1282, Inggelenelane 1310-11, Ingelane 1320

This is not quite as straightforward as Eilert Ekwall's statement, that "[t]he earliest instance clearly indicates a meaning 'the lane of the Angles," suggests. ${ }^{32}$ If this is indeed the case, it seems to be the only example of the ethnonym with an $n$-stem genitive ending ( ${ }^{*}$ Englena). Given the tendency of other ethnonyms to vary in declension between $i$ - and $n$-stem, a variant $n$-stem form is by no means impossible. It is unusual, though of course not unique, for as full a form as Englene- to be preserved in the written record as late as the late 13th century, even for group-names for which we have better evidence of an $n$-stem derivation. Contextual evidence may support Ekwall's proposed etymology, as there is a small corpus of ethnonym + routeway names: Denver, Norfolk ('Danes' passage', OE far ); the compounds with ON gata 'road' listed below under Sash

29 Cox, Place-Names of Leicestershire, part 6, p. 175; Smith, Place-Names of the West Riding, part 5, p. 177, and see also Markington, p. 179; J. McN. Dodgson, The Place-Names of Cheshire, 5 parts in 7 vols (Cambridge 1970-72, Nottingham. 1981-87), part 4, p. 193. Flemmingfield in Durham looks like a possible example, but probably contains a surname; Allen Mawer, The Place-Names of Northumberland and Durham (Cambridge, 1920), p. 87; CDEPN, p. 45 .

$30 \quad$ Sandred, English Place-Names in-stead, p. 275.

31 Eilert Ekwall, Street-Names of the City of London (Oxford, 1954), p. 123.

32 Ekwall, "Tribal Names," p. 139. 
Gate; there are two possible instances of Bretar/Brettas 'Britons' with OE strēt 'main road' in the north west. ${ }^{33}$

OE tūn 'farm, estate'

Engleton Hall (Staffordshire; O.S. SJ 898101) ${ }^{34}$

Hengleton 1204, Engleton c. 1206-30

The ethnonym + tūn structure is recurrent, although given the general ubiquity of tūn-names this is not surprising. Group-names with tūn include: Brettas/Bretar 'Britons', Frīsan/Frísir 'Frisians', Iras/Írar 'Irish, Goidelic speakers', Norðmenn 'Scandinavians, Norwegians', Seaxe/Saksar 'Saxons' (see below, p. 134), and probably Cumbre 'Welsh, Britons'. The distribution of these names as a group has a marked Danelaw weighting, and it is possible that many of them date to the period of Scandinavian settlement or later. ${ }^{35}$

OE $w u d u$ 'wood'

Inglewood Forest (Cumberland; O.S. NY 453391) ${ }^{36}$

Englewod'c. 1150; Engelwode c. 1158; Englewud 1227

Compare Wychwood, Oxfordshire, whose first element is the group-name Hwicce. ${ }^{37}$

With ON generics

ON by' 'farm, village'

Ingleby (Lincolnshire; O.S. SK 894778) 38 $^{38}$

Englebi 1086, c. 1115, Engleby 1166

Ingleby (Derbyshire; O.S. SK 352269) ${ }^{39}$

Englabý 1009, Englebi 1086, Engleby 1216

Ingleby (Greenhow parish, Yorkshire, North Riding; O.S. NZ 581063) ${ }^{40}$

Englebi, Engleby 1086, 1203-7

33 A.H. Smith, The Place-Names of Westmorland, 2 vols (Cambridge, 1967), part 1, p. 21; Eilert Ekwall, The Place-Names of Lancashire (Manchester, 1922), p. 224.

34 DEPN, p. 167; J.P. Oakden, The Place-Names of Staffordshire, 1 vol. so far (Cambridge, 1984), p. 37; D. Horovitz, The Place-Names of Staffordshire (Brewood, 2005), p. 248.

35 Jayne Carroll, "Identifying Migrants in Medieval England: the Possibilities and Limitations of Place-Name Evidence," in Migrants in Medieval England, ed. Joanna Story, Elizabeth M. Tyler, and W. Mark Ormrod (Oxford, forthcoming, 2020).

36 A.M. Armstrong, et al., The Place-Names of Cumberland, 3 vols (Cambridge, 1950-52), p. 38.

37 Gelling, Place-Names of Oxfordshire, part 2, p. 386.

38 Kenneth Cameron with John Insley, The Place-Names of Lincolnshire, 7 vols so far (Nottingham, 1985-2010), part 7, p. 93; $D E P N$, p. 264.

39 Kenneth Cameron, The Place-Names of Derbyshire, 3 vols (Cambridge, 1959), part 3, p. 639; DEPN, p. 264.

40 Smith, Place-Names of the North Riding, p. 167; DEPN, p. 264; CDEPN, p. 331. 
Ingleby (Barwick parish, Yorkshire, North Riding; O.S. NZ 441137) ${ }^{41}$

Englebi 1086, Caldengilbi 1279, Kaldingelby, Caldingelby 1283

Ingleby (Arncliffe parish, Yorkshire, North Riding; O.S. NZ 447009) ${ }^{42}$

Englebi, Engleby 1086, 1231, Engelby juxta Erneclyf 1303

While these names have been listed as containing an ON generic, it should be remembered that, in places which had seen Scandinavian linguistic influence as a result of settlement, by 'farm, village' may have been adopted into the local toponomasticon regardless of the cultural or linguistic identity and heritage of those areas' inhabitants. Nevertheless, bý is certainly of Scandinavian origin, it has a consistent Danelaw distribution, and it compounds with a markedly high proportion of Scandinavian first elements, including identifiably Scandinavian personal names. ${ }^{43}$ In many cases, bý-names would have arisen in Norse-speaking environments, and can be interpreted as good evidence of Scandinavian-speaking communities in the late gth century and early 10th. ${ }^{44}$ On contextual grounds an Old Norse origin for these names is most likely-the names occur within clusters of other early-attested bý-names in areas of considerable Scandinavian linguistic influence, and their etymology, 'farm or village of the English/Angles', clearly points in this direction. Ethnonym + ON bý is recurrent: examples include compounds in ON Bretar 'Britons', ON Danir/OE Dene 'Scandinavians, Danes', ON Frísir/OE Frīsan 'Frisians, ON Írar/OE İras 'Irish', and ON/OE Norðmenn 'Scandinavians, Norwegians'.

\section{OE Seaxe and ON Saksar}

As indicated above, identifying OE Seaxe- or ON Saksar-names presents considerably more difficulty than identifying Engle-names. Early spellings which suggest these ethnonyms can also suggest two other (related)

41 Smith, Place-Names of the North Riding, p. 170; DEPN, p. 264.

42 Smith, Place-Names of the North Riding, p. 178; DEPN, p. 264; CDEPN, p. 331.

43 An OE cognate $b \bar{y}$ 'village' seems to be attested once in the 1oth-century gloss to the Lindisfarne gospels, but the distribution and compounding characteristics of the element are such that its toponomastic origin is confidently attributed to Scandinavia (David N. Parsons and Tania Styles, Vocabulary of English Place-Names, BRACE-CASTER (Nottingham, 2000), pp. 104-8).

44 See Lesley Abrams and David N. Parsons, "Place-Names and the History of Scandinavian Settlement in England," in Land, Sea and Home: Proceedings of a Conference in VikingPeriod Settlement at Cardiff, July 2001, ed. John Hines, Alan Lane, and Mark Redknap (Leeds, 2004), pp. 379-431, esp. pp. 394-400. 
possibilities, and there are few definitive characteristics by means of which to differentiate the three.

(1) The weak masculine personal names OE Seaxa and ON Saxi are themselves derived from the ethnonyms. We would expect both the ethnonym and personal name, when found as the specific elements in place-names, to appear in the genitive case, and these forms are as follows:

\section{OE Seaxe (ethnonym, $n$-stem, plural) $\sim \operatorname{Seax}(e) n a^{45}$ \\ OE Seaxa (personal name, $n$-stem, singular) $\sim$ Seaxan}

At first glance, this looks promising - the plural and singular genitive forms are distinct, and therefore possible to tell apart. That this difference might, however, be difficult to detect in place-names can be demonstrated by looking at some of the early spellings for Exton in Hampshire. ${ }^{46}$

cet east seaxnatune 940 (S 943; 12th-cent. MS)

Essessentune 1086

Estsexentun c.1127

Exton 1182

In the earliest, pre-Conquest attestation, it is very clear that we are dealing with seaxna-, the genitive plural form of the ethnonym Seaxe. We have here a diagnostic spelling, and seaxnatune must mean 'settlement/estate of the [East] Saxons'. By Domesday Book in 1086, though, this distinctive ending has reduced to -en. Were it not for the pre-Conquest spelling, we could not be confident, on formal grounds at least, that it is a reduction of -ena; it could represent a reduced form of genitive singular -an (although see further discussion under Saxondale, p. 126). The 1182 form serves as a further warning that complete loss of a genitive plural inflection (or indeed a genitive singular inflection) was also possible by a relatively early date. Original -ena- might only survive in Middle English (ME) spellings as $<\mathrm{e}>$, or it might disappear altogether. In short, if we do not have pre-Conquest attestations we are unlikely to have diagnostic spellings which point clearly to underlying -ena or -an, and relatively few settlement-names are attested before the Domesday Survey.

45 The ethnonym seems to have been an original $n$-stem noun which transferred to the $i$-stems while retaining the original gen. pl. inflection; Hogg and Fulk, A Grammar of Old English: Morphology, §2.70.

46 Coates, Place-Names of Hampshire, p. 74; CDEPN, p. 222. 
We should also probably reckon with an alternative OE genitive plural Sea$x a$, modelled on $i$-stem ethnonyms, including Engle. ${ }^{47}$ This may be evidenced in supsaxa lond c.848 (S1193;13th-cent. MS). ${ }^{48}$ Again, here we have a pre-Conquest spelling which seems to preserve the distinctive $-a$ ending of this $i$-stem genitive plural, but the quality of the vowel in compounds would have become less distinct and represented in later medieval sources as $<\mathrm{e}>$. A run of late medieval spellings with medial $-e$ - is therefore indicative of an earlier inflection; but it could be the remnant of the plural forms -ena, $-a$, or of singular -an.

It has also been argued that the root of an ethnonym such as OE Seaxe might sometimes have been used uninflected in place-names as Seax- ${ }^{49}$ Ekwall suggested this for Saxham in Suffolk, Saxton in West Yorkshire, and Saxon Street in Cambridgeshire, but it should be noted that most of his suggested analogues for such uninflected ethnonyms are names of territories or kingdoms (Seaxland, Scotland and Francland) rather than settlement-names.

The Old Norse equivalents, plural ethnonym Saksar and singular personal name Saxi, have indistinguishable genitive forms, Saksa and Saxa (using <ks> and $\langle\mathrm{x}\rangle$ to distinguish is a modern spelling convention)—we simply cannot tell, on formal grounds, which we are dealing with. And again, these - $a$ inflections would reduce over time to -e-, or disappear altogether.

(2) The neuter nouns OE seax, ON sax 'dagger, sword' (the ethnonym derives ultimately from the etymon of these two cognates), may be used in placenames with a transferred sense, usually taken to describe (a) a stream, hill or other landscape feature which in some way resembles a dagger; (b) dagger-like flora; (c) cultural practices of weapon deposition in watery features. The first of these, especially in reference to streams, is the more securely attested (see Saxcemede, below). In such cases, when used as the first element in compounds, we would expect spellings in seax-, whether from an originally uninflected form or from a genitive singular seaxes reduced through dissimilatory loss. It should here be noted that the ON cognate of seax might also be reckoned with in English place-names, given its occurrence in Scandinavian river-names (see Saxcemede, below, and references cited there). The second application, posited by Kitson (see Seaxa broc, below), might entail use in the genitive plural (sea$x a$ ), which would render it formally indistinguishable from the $i$-stem genitive plural of the ethnonym noted above. The third possibility has not generally

47 Campbell, Old English Grammar, §610(7); Hogg, Grammar of Old English, §2.70.

48 S 1193; Cullen, "The Place-Names," p. 217.

49 O.S. Anderson, Hundred-names of the South-Western Counties (Lund, 1939), p. 141; Ekwall, "Tribal names," pp. 135-36; Reaney, Place-Names of Cambridgeshire, pp. 133-34; A.H. Smith, English Place-Name Elements, 2 vols (Cambridge, 1956), part 2, p. 116; A.D. Mills, The Place-Names of Dorset, 4 vols so far (Cambridge, 1977-), part 3, pp. 104-05. 
been considered in the place-name literature, but ritual deposition of this nature is attested in early medieval and post-Conquest England..$^{50}$ If such practices could give rise to seax place-names, then this application might be reckoned with for any place-name whose generic refers to a feature associated with wetland or rivers. A meaning 'cliff, stone, rock' has been proposed, but is not widely accepted..$^{51}$

To summarise, Seax(e)na-forms must derive from the ethnonym Seaxe, but the reduced form Seaxen- might derive either from Seaxe or from the personal name Seaxa; while the reduced forms Seaxa-, Seaxe-, and Seax- might derive from either of those or from OE seax. $S(e) a x a-, S(e) a x e-$, and $S(e) a x$-forms might alternatively derive from either of the Old Norse equivalents, Saksar and Saxi. As the personal names Seaxa and Saxi presumably arose as bynames bestowed on individuals considered ethnically Saxon, the implication of ethnic otherness might still be present in place-names whose first element is this personal name. It could be argued, then, that place-names containing either the ethnonym or the personal name should be considered together. Place-names which contain seax 'dagger, sword', on the other hand, are of a different order, even if that word is thought to be the origin of the ethnonym.

The name-by-name analysis which follows takes the above considerations into account, and draws on comparative material, in order to suggest which names might usefully be considered part of the corpus of Seaxe-names.

\section{With OE generics}

OE brōc 'stream'

Seaxa broc (lost) (boundary point of an estate at Conington, Cambridgeshire; O.S. TL 158876)

Seaxa broc 957 (S 649; 10th-cent. MS)

Formally, Seaxa could be the genitive plural of the group-name or of seax 'knife'. Kitson suggested that the stream, seaxa broc 'knives' brook', was named

5o Ben Raffield, "A River of Knives and Swords': Ritually Deposited Weapons in English Watercourses and Wetlands during the Viking Age," European Journal of Archaeology 17:4 (2014), 634-55; David Stocker and Paul Everson, "The Straight and Narrow Way: Fenland Causeways and the Conversion of the Landscape in the Witham Valley, Lincolnshire," in The Cross Goes North: Processes of Conversion in Northern Europe: AD 300-1300, ed. Martin Carver (Woodbridge: Boydell and Brewer, 2003), pp. 271-288. We are grateful to Alex Langlands for bringing this to our attention.

51 Ernst Förstemann, Altdeutsches namenbuch, 2 vols (Bonn, 1913-16), 2:654-8; Anton Fägersten, The Place-Names of Dorset (Uppsala, 1933), pp. 19-20; DEPN pp. 405-6, under Saxham, Saxtead; John Kousgård Sørensen, Dansk Sø- og Ånavne (Copenhagen, 1968-96), vol. 2 (1973), pp. 231-32. 
from the sharpness of its rushes. ${ }^{52}$ Ritual deposition of weapons might also be reckoned with. The stream has been identified with Holme Brook, ${ }^{53}$ and forms part of the northern boundary of the estate at Conington, which ran lang broces on gyruwan fen 'along the brook to gyruwan fen., ${ }^{54}$ Whitsun Brook in Worcestershire (wixena 'of the Wixan') and-less certainly-Walbrook in Middlesex (weala 'of the Britons') are possible comparable names. ${ }^{55}$

OE brycg 'bridge'

Sackbridge (lost) (in Bottisham, Cambridgeshire; O.S. TL 5466o6)

Saxbriggemore 1391, Saxbrugge 1429

P.H. Reaney takes this to be uninflected Seax, thus perhaps 'Saxon-bridge'.56 The forms are late, but possible parallels to such a compound can be found: $l a$ Denebrygg' 1303 is closely analogous if its first element is OE Dene 'Danes' (gen. pl. Dena); so too, perhaps, Weala brucge (944 [S 500; MS c.1240]), with OE walas 'Welsh (speakers)' (gen. pl. weala), ${ }^{57}$ although in each of these cases a genitive inflection appears to be preserved. Also of relevance are the several instances of ethnonyms compounded with other elements referring to river crossings, such as OE ford in Denford (Northamptonshire; Dene) and Orford (Lincolnshire; OE Iras 'Irish; Goidelic speakers'). ${ }^{58}$ Given the possibility that OE seax was used as a river-name (see Saxcemede, below), a similar explanation should also be entertained here, although compounds of brycg with rivernames are relatively rare. ${ }^{59}$

OE cot 'cottage, hut'

\section{Sascott (Shropshire; O.S. SJ 425118)}

Saxcote 1086, Sayscot 1274, Saxecot 1308

Sessacott (Devon, O.S. SS 355165)

Saxecot' 1219

52 P.R. Kitson, A Guide to Anglo-Saxon Charter Boundaries (forthcoming).

53 Susan Oosthuizen, The Anglo-Saxon Fenland (Oxford, 2017), p. 59.

54 C.R. Hart, The Early Charters of Eastern England ([Leicester], 1966), pp. 23-24. Gyruwan may be an instance of another group-name, Gyrwe.

55 Allen Mawer, F.M. Stenton, and F.T.S. Houghton, The Place-Names of Worcestershire (Cambridge, 1927), p. 16; Gover, Mawer, and Stenton, Place-Names of Middlesex, p. 7.

56 Reaney, Place-Names of Cambridgeshire, p. 128.

57 Parsons and Styles, Vocabulary, BRACE-CESTER, p. 54; Gelling, Place-Names of Berkshire, pp. 643-44.

58 See Carroll, "Identifying Migrants."

59 Margaret Gelling and Ann Cole, The Landscape of Place-Names (Stamford, 2000), p. 69, and see also the entry for brycg in Parsons and Styles, Vocabulary, BRACE-CESTER, pp. $51-57$. 
There is little early evidence of an original inflection in the forms for the Shropshire name, but $\mathrm{OE}$ seax 'dagger' is an unlikely recurrent first element with $\mathrm{OE}$ cot 'cottage, hut', even in a transferred sense; so an uninflected form of Seaxe or early reduction of a medial inflection might be considered. That means both ethnonym and personal name are possible for these place-names, and the latter was preferred both by J.E.B. Gover, Allen Mawer and Frank Stenton, and by Margaret Gelling. ${ }^{60} \mathrm{OE}$ cot is very rarely compounded with an ethnonym. An apparent exception is OE wala-cot, but while the primary sense of $\mathrm{OE}$ walh was 'Welsh (speaker)', it developed a secondary meaning 'serf', and this might be the relevant sense in those compounds. A compound meaning 'cottage(s) of the serfs' would be directly comparable with recurrent compounds such as gebüra-cot 'cottage(s) of the (tied) peasants' and ceorla-cot 'cottage(s) of the peasants', swäna-cot 'cottage(s) of the herdsmen or peasants', ${ }^{61}$ and not therefore relevant in the present case. Compounds of $\mathrm{OE}$ cot with personal names, on the other hand, are relatively common. The personal name Seaxa seems most likely, then, but the double occurrence of the compound in places with later survival of Welsh and Cornish cultures is noteworthy, as is the proximity of Saxworthy (discussed below), just across the River Torridge from Sessacott.

In each case, the development /saks(ə)kot/ > /sas(ə)kot/ can be explained by dissimilatory deletion of the first $/ \mathrm{k} /$. There may also have been some Brittonic influence on the development of each name: the apparent diphthong of the 1274 form for Sascott might indicate influence from Welsh Sais 'Englishman' (compare Seisdon, below); ${ }^{62}$ while it may be Brittonic prosody—placing stress on the penultimate syllable- that has preserved the medial syllable in the modern form of Sessacott.

\section{OE dcel / ON dalr 'valley'63}

Saxedele (lost field-name in Gayton Thorpe, Norfolk; approx. O.S. TF 745185) Saxedele e. 13th

\section{Saxedale (lost; in Withcall, Lincolnshire; approx. O.S. TF 285839)}

Insley treats the first element of the Norfolk name as OE Seaxe or ON Saksar, thus 'valley of the Saxons'. Gover, Mawer and Stenton note a mention of the

6 Gover, Mawer and Stenton, Place-Names of Devon, p. 162; Margaret Gelling, The PlaceNames of Shropshire, Parts 1-6 (Nottingham, 1990-2012), part 2, p. 54.

61 Parsons and Styles, Vocabulary, BRACE-CESTER, pp. 70-71; David N. Parsons, The Vocabulary of English Place-Names, CEAFOR-COCK-PIT (Nottingham, 2004), pp. 19-26; Smith, Elements, part 1, pp. 57, 89-90, 109; Smith, Elements, part 2, pp. 171, 242-4.

62 Gelling, Place-Names of Shropshire, part 2, p. 54.

63 ON deill 'share of land' is a possibility, but we might expect early forms to show a reflex of /eI/; see Smith, Elements, part 1, p. 128. 
apparently identical Saxedale in the Kirkstead cartulary, but provide no further information. ${ }^{64}$

\section{$\mathrm{OE}$ denu 'valley'}

\section{Saxondale (Nottinghamshire; O.S. SK 68340o)}

Saxeden 1086, Saxenden 1316; Saxendala c.1130, Saxendale 1199

This is a rare instance where post-Conquest forms may be diagnostic. There is some evidence to suggest that an original inflectional /n/ was more likely to survive in the late medieval reflexes of place-names when immediately followed by a vowel, as would have been the case with medial -(e)na-. The /n/ in place-name compounds with genitive singular -an seems generally to survive only when the following element begins with a vowel or $/ \mathrm{h} / \mathrm{plus}$ vowel. So, we might argue that the early (and current) spellings for Saxondale suggest that OE Seaxena-denu 'valley of the Saxons' is the most likely interpretation of the name. ${ }^{65}$ The second element seems to have interchanged for a while with $\mathrm{OE}$ deel 'pit, hollow; valley' or ON dalr 'main valley', which eventually supplanted it. ${ }^{66}$

\section{OE $d \bar{u} n$ 'hill'}

\section{Seisdon (Staffordshire; O.S. SO 836947)}

Saisdon hvnd', Saisdone hvnd', Seiesdon hvnd' 1086, hdr' de Saiesdona 1130, Seidon'hundredum 1182, Seisdon'hundredum 1185; Seisdone 1086, Seisdun 1160-1206 (personal name), Seyxdun 1235, 1236, Seydon'1236, Seisdon' 1242 Association of Seisdon with Seaxe or Seaxa is problematic. Anderson and others have attributed the development of $/ \mathrm{ks} />/ \mathrm{s} /$ or $/ \mathrm{z} /$ (indicated by the surviving forms and modern pronunciation) to Anglo-Norman influence. ${ }^{67}$

64 John Insley, "Scandinavian Personal Names in Norfolk," 2 vols (unpublished PhD thesis, University of Nottingham, 1980), pp. 636 and 639; John Insley, Scandinavian Personal Names in Norfolk: A Survey Based on Medieval Records and Place-Names (Uppsala, 1994), pp. 323-24; J.E.B. Gover, Allen Mawer and F. Stenton, The Place-Names of Nottinghamshire (Cambridge, 1940), p. 241.

65 Ekwall, "Tribal Names," p. 136. The environment of $/ \mathrm{n} /$ in such compounds may have facilitated its retention. Similar survival is attested for Oxford, from OE oxena-ford 'ford of the oxen', which is Oxeneford 1086, Oxineforp' c.113o, Oxineford 1316 and the identical Oxenford, which is Oxenfordam 1128, Oxeneford $1135 \times 54$, Exeneford 1291 ; Gelling, Place-Names of Oxfordshire, part 1, p. 19, Gover, Mawer, and Stenton, Place-Names of Surrey, p. 216. See also Cameron, English Place Names, p. 27.

66 Gover, Mawer and Stenton, Place-Names of Nottinghamshire, p. 241; Ekwall, "Tribal Names," p. 136.

67 R.E. Zachrisson, 'The French element', in Introduction to the Survey of English PlaceNames, Part I, ed. Allen Mawer and F.M. Stenton (Cambridge, 1933), 93-114, at p. 114; 
Although $<\mathrm{s}>$ forms begin early and are almost universal, early Anglo-Norman influence on the name of an administrative centre is feasible (Seisdon was the name of a Domesday hundred). ${ }^{68}$ Unlike most other Seaxe or Seaxa placenames, however, the spellings listed above suggest preservation of the first vowel as a diphthong. Attempts to identify it with Welsh Sais 'Englishman', which might explain the diphthong, have not been received entirely enthusiastically, and it is hard to account for an English place-name compound with Welsh Sais as first element, or for a Welsh place-name compound with OE dün as the generic. ${ }^{69}$ Welsh influence, as suggested for Sascott (above), seems rather less likely this far east, unless it occurred very early. It is hard to conclude with much conviction that Seisdon is a Seaxe place-name. ${ }^{70}$

$\mathrm{OE} \bar{e} a$ 'river, stream'

\section{Saxcemede (lost, nr Puddletown, Dorset; O.S. SY 755945)}

Saxcemede 1270 (1372 MS)

Formally both Seaxe and the personal name Seaxa are possible, given the lateness of the only surviving attestation, but A.D. Mills prefers OE *Seax-ēa 'stream called Seax', where Seax means something like 'the sword, the bright one', noting use of the ON cognate $\operatorname{sax}$ in Scandinavian river-names. ${ }^{71}$ Ritual deposition of weapons might be an alternative explanation of the use of seax in such names. (Compare also Seaxa broc, above.) Either of these is probably more attractive than derivation from a compound such as Seaxa-méd 'meadow of the Saxons', since OE méd is rare as the second element in compounds with an ethnonym. Compare Common Mead in Dorset (Comermede 1300), where the first element might be Cumbre 'Britons', but Mills prefers a personal name

compare also the discussion of Saxlingham in Eilert Ekwall, English Place-Names in -ing, second edition (Lund, 1962), p. 138; DEPN, p. 411.

68 In addition to the $<\mathrm{x}>$ spelling listed above, there is Sexedon 1428 , and there are forms with neither $\langle\mathrm{s}\rangle$ nor $\langle\mathrm{x}\rangle$. Sascott and Sessacott, where $/ \mathrm{ks} /$ has developed to $/ \mathrm{s} /$, do at least have early spellings in $\langle\mathrm{x}\rangle$, and the development in those cases is more easily explained by dissimilation in the cluster [ksk].

69 W.H. Duignian, Staffordshire Place-Names (London, 1902), pp. 132-3 (incorporating a note by W.H. Stevenson); O.S. Anderson, English Hundred-Names (Lund, 1934), p. 145; Richard Coates and Andrew Breeze, Celtic Voices, English Places (Stamford, 2000), p. 335; Horovitz, Place-Names of Staffordshire, p. 482; DEPN, p. 411; Gelling and Cole, Landscape, p. 169.

70 Anderson, English Hundred-Names, p.145 makes some tentative alternative suggestions.

71 Mills, Place-Names of Dorset, part 1, p. 328; Sørensen, Dansk Sø- og Ånavne, vol.2, pp. 231-2; Danmarks Stednavne <http://danmarksstednavne.navneforskning.ku.dk/>, s.v. Gladsaxe (accessed 1 March 2018). 
Cumbra $;{ }^{72}$ and Walmead in Wiltshire (Walemade 1100-35), with OE walh 'Briton; serf' (and see the discussion of wala-cot under Sascott, above). ${ }^{73}$

OE feld 'open land'

Saxfield (Cheshire; O.S. SJ 823901)

Saxefeld 13th cent., c.1290, Saxe Felde 1578

Saxifield (Lancashire; O.S. SD 862352)

Saxifeldyk 1324, Saxxefeld 1425, Saxyfeld 1507

For the first of these names, either OE Seaxa-feld or Seaxena-feld 'open land of the Saxons' is formally acceptable, ${ }^{74}$ but so is Seaxan-feld 'open land of a man named Seaxa'. For Saxifield, spellings with medial $<\mathrm{i}>$ and $<\mathrm{y}>$ seem problematic and earlier attestations would be required to establish their precise significance. Ekwall suggests a personal name as first element, either OE Seaxa or ON Saxi. ${ }^{75}$ The genitive inflections would normally be reduced to /ə/, giving ME spellings in $<\mathrm{e}\rangle$, as also (in most instances) the genitive plural inflection of OE Seaxe. The $<\mathrm{i}>$ and $<\mathrm{y}>$ may simply stand for $/ \mathrm{\partial} /$, or else we may be dealing with an unattested OE *seaxing 'knife-shaped feature', if the topography is appropriate (much of the area is now built up). It is worth noting that personal names often form the specific in compounds with OE feld, ${ }^{76}$ but the twin occurrence of the collocation of Sax- with OE feld is perhaps suggestive of the ethnonym rather than a personal name. It might be compared with Englefield (above), and the other examples of ethnonym + feld noted there.

OE halh 'nook'

Saxehale (lost, nr Stutton in Tadcaster, West Riding of Yorkshire; O.S. SE 479415)

\section{Saxehale, Saxhale, Saxhalla 1086}

This is another of the rare occasions when the post-Conquest forms may be partly diagnostic. With no more than Domesday to go on, caution is required, but the surviving spellings probably rule out both Seaxena-halh and Seaxanhalh. When followed by $/ \mathrm{h} /$ plus vowel, some trace of the $/ \mathrm{n} /$ might be expected. This might therefore be OE Seaxa-halh 'nook of the Saxons', or perhaps OE

72 Mills, Place-Names of Dorset, part 3, p. 19.

73 J.E.B. Gover, Allen Mawer and F.M. Stenton, The Place-Names of Wiltshire (Cambridge, 1939), p. 198.

74 Dodgson, Place-Names of Cheshire, part 1, p. 236.

75 Ekwall, The Place-Names of Lancashire, p. 83.

76 Gelling and Cole, Landscape, p. 274. 
seaxa-halh 'daggers' nook', if characterized by particularly dagger-like flora (compare Seaxa broc, above). ${ }^{77}$

\section{OE hām 'homestead, settlement'}

\section{Great/Little Saxham (Suffolk; O.S. TL 794632)}

Saxham 1086, 1197, Sexham 1086

There is no evidence for an originally inflected first element, and the forms count against Seaxena- or Seaxan- (see the preceding entry), casting doubt on Walter Skeat's interpretation of the first element as a personal name. Ekwall suggests OE *Seax-häm 'homestead of the Saxons', rejecting OE seax in a topographical application and (on formal grounds) the personal name. ${ }^{78}$ Victor Watts also prefers the ethnonym, as do Keith Briggs and Kelly Kilpatrick, though they offer the personal name as an alternative. ${ }^{79}$ It should be noted that OE hām 'homestead', or OE hamm 'enclosed land' (from which häm can be hard to distinguish in place-names), occur rarely in compounds with ethnonyms: there are few if any certain instances with reference to groups of Angles, Jutes, Danes, Frisians or Northmen; only with OE Swëfe 'Swabians' has such a compound been proposed with any great force. ${ }^{80}$

OE mearc 'boundary'

\section{Seaxana meare (lost, nr Warehorne (?), Kent; O.S. TQ 985325)}

Seaxana meare 845 for 830 (S 282; 11th-cent. MS)

Paul Cullen follows Wallenberg in taking the second element to be OE mearc, and the first element is clearly a weakly inflected genitive plural of OE Seaxe, thus 'boundary of the Saxons. ${ }^{81}$

OE sēað 'pit'

seaxe seað (Slackstead, Hampshire; approx. O.S. SU 396257)

77 Smith, Place-Names of the West Riding, part 4, p. 76 .

78 He accepts the latter as a possibility in $D E P N$, pp. 405-6, but rejects it in "Tribal Names," p. 136

79 Walter W. Skeat, The Place-Names of Suffolk (Cambridge, 1913), p. 59; DEPN, p. 405-6; CDEPN, p. 529; Keith Briggs and Kelly Kilpatrick, A Dictionary of Suffolk Place-Names (Nottingham, 2016), p. 118-19.

$80 \quad$ Reaney, Place-Names of Cambridgeshire, p. xxxiii, p. 133-34; DEPN, p. 455; CDEPN, p. 592. Compounds of häm with -ingas group names (if they are comparable) are, however, common; see J. McN. Dodgson, "The Significance of the Distribution of the English PlaceNames in -ingas, -inga- in South-East England," Medieval Archaeology 10 (1966), 1-29; Barrie H. Cox, "The Significance of the Distribution of English Place-Names in -hām in the Midlands and East Anglia," JEPNS 5 (1972-73), 15-73, at pp. 50-61.

81 Wallenberg, Kentish Place-Names, p. 165; Cullen, “The Place-names," p. 253. 
on seaxea seað of seaxe seaðe, on seaxe seaðe goo ( $\mathrm{S}_{360}$; early uth-cent.

MS); on seaxes seaðe $899 \times 924$ ( 3881 ; 12 th-cent. MS)

Grundy takes this to be a personal name, or rather a by-name, thus 'Saxon's Pit'. ${ }^{82}$ We may then be dealing with an unattested strong personal name *Seax, comparable with the Scandinavian name discussed under Saxthorpe, if the form in $\mathrm{S}_{3} 81$ is the more reliable. The other forms might result from reanalysis of seaxes seaðe as seaxe seaðe, but the process could be the other way round. Kitson notes an association of sēað with watery features, so another instance of seax-êa as a river-name is possible (whatever the motivation, see Saxcemede), or a reference to dagger-like rushes (see Seaxa broc), although the spellings do not necessarily indicate a genitive plural form.

OE stede 'place'

Saxstead (Suffolk; O.S. TM 265655)

Saxsteda (Skeat gives Saxteda)

Skeat is followed by Ekwall (who considers but rejects OE *seax 'rock'), Mills, Watts, and Briggs and Kilpatrick in assuming a personal name Seaxa, with OE stede 'place. ${ }^{33}$ Few forms listed by any of these commentators could be considered diagnostic of that personal name in preference to the ethnonym, so $\mathrm{OE}$ Seaxe is at least a possibility. The only other possible instance of ethnonym + stede is Irstead in Norfolk. Its early forms do not rule out a form of OE İras 'Irish' as first element, but $\mathrm{OE}$ gyr 'mud, filth, marsh' has been preferred by commentators. $^{84}$

OE tūn 'farm, estate'

Saxton (West Yorkshire; O.S. SE 476369)

Saxtun, Saxtuna, Saxton, Saxtuna 1086

Saxon Street/Saxton Hall (Cambridgeshire; O.S. TL 675595)

Sextuna, Sextone 1086, Sexton, Sextone 1208 Cur (personal name), Saxton, Saxtone 1236

82 G.B. Grundy, "The Saxon land charters of Hampshire with notes on place and field names, 1st series," Archaeological Journal 2nd series, 28 (1921), pp. 55-173, at p. 83; G.B. Grundy, "The Saxon Land Charters of Hampshire with Notes on Place and Field Names, 2nd series," Archaeological Journal 2nd ser., 31 (1924), 31-126, at p. 119.

83 Skeat, Place-Names of Suffolk, p. 88; DEPN, p. 406; A.D. Mills, The Oxford Dictionary of British Place-Names (Oxford, 2003), p. 408; CDEPN, p. 529; Briggs and Kilpatrick, Suffolk PlaceNames, p. 119 .

84 Sandred, English Place-Names in -stead, p. 183;DEPN, p. 266, CDEPN, p. 333. 
For the first of these names, A.H. Smith noted the possibility of a connection with Saxons, but preferred a personal name..$^{85}$ For the second, Reaney was unconvinced by Seaxe for lack of ME forms with medial <e $>$, and felt that $\mathrm{OE}$ *seax 'hill' was topographically inappropriate; ${ }^{86}$ he therefore posits the root Seax- used in compound to mean 'Saxon'.87 Certainly there is no reflex of an original inflection in the forms listed here, although, as noted above, that need not rule it out. Compounds of the type ethnonym + tūn are recurrent (see discussion of Engleton, above).

\section{OE worðig 'enclosure'}

Saxworthy (Devon; O.S. SS 375175)

Sexaworthi 1330

Gover, Mawer and Stenton take the first element to be a personal name, but OE Seaxe cannot be dismissed on formal grounds. ${ }^{88}$ Saxworthy is located just across the River Torridge from Sessacott, and a connection with that name is possible.

\section{With Brittonic generics}

Welsh pen 'chief, head; promontory'

\section{Pensax (Worcestershire, O.S. SO 725695)}

Pensaxan (dat.) 11th cent. ${ }^{89}$

This is a Brittonic place-name, formed as a name-phrase from the ancestors of Welsh pen 'head, top', and Sais 'Englishman, Saxon'. ${ }^{90}$ This accounts for the

85 Smith, Place-Names of the West Riding, part 4, p. 70; part 7, p. 50.

86 It is also worth noting that * seax might have been used of some sword-shaped feature other than a hill.

87 Reaney, Place-Names of Cambridgeshire, pp. 127-8. The field-names Little Sextons and Sextons Lances, in Tolleshunt Knights (Essex; Sextynegrove 1291), may be instances of the occupational byname Sexton, which is on record from the 14th century; in 1881 it was most common as a surname in East Anglia and the south-east. The names are listed in P.H. Reaney, The Place-Names of Essex (Cambridge, 1935), p. 616. Sexton is discussed in Patrick Hanks, Richard Coates and Peter McClure, eds., The Oxford Dictionary of Family Names in Britain and Ireland (Oxford, 2016), s.v. "Sexton," online at <http://www.oxfordreference. com/view/10.1093/acref/9780199677764.001.00o1/acref-9780199677764-e-36576\&gt> (accessed 26 Jan. 2017).

88 Gover, Mawer and Stenton, Place-Names of Devon, p. 107.

89 Hemingi chartularium ecclesice Wigorniensis, ed. Thomas Hearne, 2 vols (Oxford, 1723), 1:246.

90 Mawer, Stenton, and Houghton, The Place-Names of Worcestershire, pp. xliii and 67; Ekwall, "Tribal Names," p. 138; DEPN, p. 362; Kenneth Jackson, Language and History in Early Britain (Edinburgh, 1953), p. 539; Mills, Place-Names of Dorset, part 3, p. 105; Coates and Breeze, Celtic Voices, pp. 11 and 341;CDEPN, p. 467. Padel, Cornish Place-Name Elements, 
order of the elements - the generic element pen precedes the ethnonym specific. It should be considered alongside the lost name Pensousen (1582; Cornwall), and Pennersax (or Pennersaughs) in Annandale (Middlebie, Dumfries, Scotland; Penresax 1194, Pennyrsax 1194), ${ }^{91}$ name-phrases containing reflexes of the same elements.

\section{Sixpenny Farm (Dorset; O.S. ST 844169)}

seaxpennes 932 (S 419; 15-cent. MS), Sexepenne 1340 (personal name) Sixpenny was also the name of an 11th-century hundred (Sexpene 1084), part of the later hundred of Sixpenny Handley. ${ }^{92}$ R.E. Zachrisson suggested 'Saxons' mountain top', but this was rejected by Anton Fägersten, who preferred $\mathrm{OE}$ *seax in the sense 'cliff, stone. ${ }^{93}$ While that sense is unrecorded, it is clear that the first element could be an instance of the transferred use of OE seax in reference to a topographical feature. Mills, however, follows Zachrisson's interpretation of the first element as the uninflected root of OE Seaxe; the generic is ultimately of Brittonic origin, but was perhaps borrowed into some $\mathrm{OE}$ dialects. ${ }^{94}$ It is difficult, however, to consider this name without reference to Pensax, Pensousen and Pennersax. In each of those examples, the name is apparently a reference by Brittonic speakers to a headland or similar feature associated with one or more Saxons, and the recurrence of the association with pen suggests that the collocation may have been a feature of Brittonic lexis. In view of that, it is tempting to see Sixpenny as a further example of the same Brittonic elements present in those names, with the same meaning, but formed as a true compound, with specific preceding generic. Compounds seem generally to have been favoured in the Brittonic languages up to the 5 th century, namephrases from the $5^{\text {th }}$ century onwards, which would require Sixpenny to have been coined very early in the Anglo-Saxon period; but Oliver Padel points out that this general rule is not a hard and fast one, and that true compounds could

p. 210 and p. 294; Smith, Elements, part 2, p. 98; 'Addenda and Corrigenda', JEPNS 1 (19689), 51 .

91 William J. Watson, The History of the Celtic Place-Names of Scotland (Edinburgh and London, 1926), pp. 180, 356; Edward Johnson-Ferguson, The Place-Names of Dumfriesshire (Dumfries, 1935), p. 94; Jackson, Language and History pp. 539-40; Alan James, Brittonic Language in the Old North: Volume 2 -Dictionary (2014), p. $343<$ http://spns.org.uk/resources/bliton> (accessed 18 May 2018).

92 Anderson, South-Western Counties, p. 140-41.

93 Fägersten, Place-Names of Dorset, pp. 19-20, 24.

94 R.E. Zachrisson, Romans, Kelts and Saxons in Ancient Britain (Uppsala, 1927), 49; Mills, Place-Names of Dorset, part 3, pp. 104-5; Anderson, South-Western Counties, p. 141; CDEPN, p. 276 , under Handley. 
be used in the coining of place-names at a later date. ${ }^{95}$ Chronologically, there seems little reason to rule out the possibility that Sixpenny originated as a Brittonic place-name, even if its surviving forms are the result of Anglicization. A difficulty with this interpretation, however, is the dearth of evidence for pen as the generic in early Brittonic place-names. ${ }^{96}$

\section{With ON generics}

ON bý

\section{Saxby (Leicestershire; O.S. SK 820201)}

Saxebi 1086, Sessebia c.1130, Saxenebi 1175, 1198

Saxby All Saints (Lincolnshire; O.S. TF oo4861)

Saxebi 1086, 1166

\section{Saxby (Lincolnshire; O.S. TF oo5862)}

Sassebi 1086, Saxsabi, Saxsebi c.1115, Saxebia c.1155

These three compounds in ON by 'farm, settlement' should be treated together, although different etymologies have been proposed. Formally they could all contain a reference to Saxons. The late 12th-century forms for the Leicestershire Saxby point to the genitive plural form of OE Seaxe (Seax (e)na), ${ }^{97}$ although it is possible that these spellings represent a 'translation' or reanalysis of an underlying Old Norse specific. All other spellings could represent either OE Seaxe or ON Saksar. While an ethnonym interpretation was favoured by Fellows Jensen, ${ }^{98}$ Ekwall and others have preferred the ON personal name Saxi, citing the frequency with which this personal name occurs in eastern England as an explanation for the recurrence of the same compound. ${ }^{99}$ The compound Ingla- or Engla-bý, discussed above, is also recurrent, as are Dena- or Dana-bý 'settlement of the Danes', Frīs(en)a- or Frísa-by 'settlement of the Frisians'. The

95 Padel, Cornish Place-Name Elements, pp. xiv-xvi.

96 A.L.F. Rivet and Colin Smith, The Place-Names of Roman Britain (London, 1979), p. 436 only note it in Pennocrucium, and the continental parallels they cite also have pen as first element. Padel finds no instances of Cornish pen as the generic in a place-name compound, although it does occur in name-phrases, CoPNE p. 178. See also the useful discussion of pen in Oliver Padel, "Brittonic place-names in England," in Perceptions of Place, ed. Jayne Carroll and David N. Parsons (Nottingham, 2013), pp. 1-41, at pp. 32-34.

97 Cox, Place-Names of Leicestershire, part 2, p. 135.

98 Gillian Fellows Jensen, Scandinavian Settlement Names in the East Midlands (Copenhagen, 1978), p. 66.

$99 D E P N$, p. 405. Cameron, Place-Names of Lincolnshire, part 2, p. 254; part 6, p. 203 . See also Insley, "Scandinavian Personal Names," pp. 636-39. That etymology is also allowed by B. Cox, "The Place-Names of Leicestershire and Rutland" (unpublished PhD thesis, University of Nottingham, 1971), p. 166; Place-Names of Leicestershire, part 2, p. 135. CDEPN, p. 529 gives “Saks's village" for Saxby in Lincolnshire but "Saxons' village” for the other two. 
Saxby names fit within this pattern and should probably be derived from an ethnonym, whether OE Seaxe or ON Saksar.

ON gata 'road' (or late OE gate)

Sash Gate (Lincolnshire; O.S. TF o62947)

Saxgate $1280 \times 85$

Cameron offers both the ON personal name Saxi and uninflected OE Seaxor ON Saks-. If the latter, the place-name would mean the road of the Saxons. ${ }^{100} \mathrm{ON}$ gata is several times compounded with other ethnonyms (see also Ing Lane, above), including Jubbergate (Brettegata 1145-55) in York, from ON bretta-gata 'road of the Britons'; ${ }^{101}$ four instances in Lincolnshire of $\mathrm{ON}{ }^{*} D a$ na-gata 'road of the Danes' and three possible instances of *Norðmanna-gata, two in Leicestershire and one in Northamptonshire;102 Flemingate in Beverley, Yorkshire (ON Flcemingjar 'Flemings'); the lost Scotgate in Lincolnshire (OE Scott 'Irish person, Scots Gael'). ${ }^{103}$ This makes a compound ON Saksa-gata 'road of the Saxons' a strong possibility.

ON porp 'secondary settlement'

Saxthorpe (Norfolk; O.S. TG 115305)

Saxthorp, Saxiorp, Sastorp 1086, Saxtorpe 1146-8, Sakesthorp $1244^{104}$

Sandred takes this to contain the personal name Saxi, but Insley believes the spellings to be indicative of a strong form *Saks, which seems to occur in Danish place-names. ${ }^{105} \mathrm{ON}$ porp is compounded with ethnonyms in a small number of cases, such as Friesthorpe (Lincolnshire) and Danthorpe (Yorkshire), ${ }^{106}$ but is common with personal names (especially within the Danelaw). ${ }^{107}$

100 Cameron, Place-Names of Lincolnshire, part 3, p. 88.

101 A.H. Smith, Place-Names of the East Riding of Yorkshire and York (Cambridge, 1937), p. 291.

102 There are four instances of $\mathrm{ON}{ }^{*}$ Danagata in Lincolnshire and three possible instances of *Norðmanna-gata, two in Leicestershire and one in Northamptonshire -Cameron, PlaceNames of Lincolnshire, part 3, p. 29, part 5, pp. 12, 34, 75, Cox, Place-Names of Leicestershire, part 2, pp. 30, 198, and J.E.B. Gover, Allen Mawer, and F.M. Stenton, The Place-Names of Northamptonshire (Cambridge, 1933), p. 233;

103 Smith, Place-Names of the East Riding, pp. 195, 291; Cameron, Place-Names of Lincolnshire, part 2, p. 103 .

104 Karl Inge Sandred, The Place-Names of Norfolk, 3 vols so far (1989-), part 3, p. 98.

105 Insley, Scandinavian Personal Names in Norfolk: A Survey, pp. 323-24.

106 Cameron, Place-Names of Lincolnshire, part 7, p. 59; Smith, Place-Names of the East Riding, p. 53 .

107 Paul Cullen, Richard Jones and David N. Parsons, Thorps in a Changing Landscape (Hatfield, 2011), pp. 46-51, 64-66. 


\section{Summary of Seaxe and Saksar}

It will be clear that most of these names could contain Seaxe or Saksar, but only a small number can be identified as secure instances, where the early spellings are diagnostic or strongly suggestive of the ethnonym in preference to alternative explanations. These are Saxondale, Seaxana meare and Pensax (although this instance is Brittonic rather than OE or ON). Rather more names contain probable instances of the ethnonym: Seaxa broc, Sackbridge, Saxedele, ?Saxedale, Saxehale, Saxham, Saxfield, Saxifield, Saxton, Saxon Street, Sixpenny, the three Saxby names and Sash Gate. All of these have acceptable (sometimes favourable) early forms, while onomastic parallels provide strong contextual arguments for their inclusion. Most of the remaining names have acceptable forms, but no strong contextual reason for favouring the ethnonym over other explanations. They are no more than possible examples of the ethnonyms, and in many cases are more likely to contain a personal name or the substantive element seax: Sascott, Sessacott, Saxcemede, Saxstead, Saxworthy and Saxthorpe. In the case of Seisdon, a different etymology may need to be sought.

\section{$\mathrm{OE}{ }^{*} \bar{E}$ ote $\left({ }^{*} \bar{Y}\right.$ te,${ }^{*} \bar{I}$ ote $)$}

Alistair Campbell stars these, presumably because the nominative form is, essentially, hypothetical; ${ }^{108}$ an indication of just how rarely Jutes seem to be mentioned in Old English texts. The corpus of place-names traditionally identified as containing OE Éte is small and not especially well attested. It is set out below in alphabetical order, rather than grouped by generic.

\section{Bishopstoke (Hampshire; O.S. SU 465195)}

(apud) itinstokan 959 (14th-cent. MS), (cet) yting stoce 96o (S 683; 12thcent. MS), Stoches $1086^{109}$

Richard Coates cautiously notes that the import of the forms "is obscure, but they may contain a reference, of very great antiquity, to Jutes." He points out, however, that the form Yting "appears to be a singular -ing name here,"110 which weighs against that etymology. Gelling suggested a personal name derived from the ethnonym (compare Eatenden, below), and Insley takes the

\footnotetext{
108 Alistair Campbell, Old English Grammar (Oxford, 1959), §610 (7), p. 245.

109 J.E.B. Gover, "Hampshire Place-Names" (unpublished typescript), p. 67; Coates, PlaceNames of Hampshire, p. 34.

110 Coates, Place-Names of Hampshire, p. 34.
} 
compound to mean 'place associated with the Jute(s)'.111 The final element is OE stoc 'outlying settlement', which otherwise does not seem to be attested with ethnonyms.

\section{Eadens near East Meon (Hampshire; approx. O.S. SU 679221)}

Ytedene 1263, 1301, 1453, Itedene 1350, Eadens 1840

Gover takes this to be 'valley of the Jutes', OE *Y'te (the West Saxon variant of ${ }^{*} \bar{E}$ ote) with OE denu. ${ }^{112}$ The forms certainly allow for an original $\bar{Y} t e n a-$ or $\bar{Y} t a-$ denu, but the personal name posited for the preceding entry is again possible.

\section{Eatenden (Mountfield, Sussex; O.S. TQ 730186)}

Itintune 12th cent., Ytenton, Itenton c.1200, Ytintun 1261

This does not seem previously to have been considered in connection with OE $\bar{E}$ ote. It has been interpreted as an OE -ingtün compound based on an unattested personal name *Ita, a pet form of dithematic personal names in $I d$ - or Ith-, and a cognate of oH G Izo. The place-name could thus be interpreted as 'Ita's farm or settlement'.113 The forms, however, bear comparison with those listed under Bishopstoke and Eadens, and it therefore merits inclusion in this corpus. There is no reason to assume that the initial vowel was a short oneindeed, the modern form suggests a long vowel. The early spellings, as they stand, would not rule out OE *Ỹtena-tün 'farm or settlement of the Jutes', or an -ing formation comparable with that proposed for Bishopstoke. ${ }^{114}$

\section{Ytene, associated with the New Forest (Hampshire) in Nova Foresta, quae lingua Anglorum Ytene nuncupatur c.1115}

111 Gelling, Place-Names of Berkshire, p. 403; John Insley, "Meanware," Reallexikon der Germanischen Altertumskunde 19 (2001), 473-76, at p. 475; and note CDEPN, p. 6o, 'at the farm called Yting, the Jutes' place'.

112 Gover, "Hampshire Place-Names," p. 63a; see also Insley, "Meanware”; Barbara Yorke, "The Jutes of Hampshire and Wight and the Origins of Wessex," in The Origins of Anglo-Saxon Kingdoms, ed. Steven Bassett (Leicester, 1989), pp. 84-96, 256-63, at p. 90.

113 Allen Mawer and F.M. Stenton, with J.E.B. Gover, The Place-Names of Sussex (Cambridge, 1929-30), p. 475 and compare p. 358; Richard Coates, "Preparatory to A Dictionary of Sussex Place-Names: A,E,I,O,U. Working Paper” (UWE Research Repository, 2017, available from: http://eprints.uwe.ac.uk/30943), p. 22. Compare also Ernst Förstemann, Altdeutsches namenbuch (Bonn, 1900), p. 944.

114 The early forms of Itford in Beddingham, Sussex (Litelforde (sic) 1086, Itesford 1215, Iteford 1242, Ytevord 1337), are too confused for inclusion in the corpus. The name is taken by Mawer, Smith and Gover, Place-Names of Sussex, p. $35^{8}$ to contain the same first element as Eatenden. In this instance, the modern forms suggest a short initial vowel, in contrast to Eadens and Eatenden, perhaps more in line with derivation from a personal name *Ita. 
The form Ytene, taken from the chronicle of John of Worcester, seems to represent West Saxon OE *Y'tena 'of the Jutes', and Ekwall suggested expanding it to ME *Ytenewode 'woodland of the Jutes'. ${ }^{115}$ In the same chronicle we have in provincia Jutarum, in Nova Foresta.16

It is unfortunate that the earliest attested of these names is so problematic as an example of $\mathrm{OE} \bar{E}$ ote. A compound $\bar{E}$ ote $+-i n g+$ stoc would be a very unusual one on two counts:-ing-suffixed ethnonyms are otherwise unattested, and $\mathrm{OE}$ stoc is rare with ethnonyms. Even if, as Gelling suggests, the first element is a personal name derived from the ethnonym, it is not direct evidence that the inhabitants were Jutes, unless it arose as a byname * $\bar{Y}$ ting 'son of the Jute'. Eadens is similarly problematic, since it could be derived from the same personal name. If that purported personal name were only identified in placenames located in and around the area thought to have been settled by Jutes, this might cast doubt on its existence; but it does seem to occur elsewhere. Edford Brook (Lilleshall, Shropshire), for instance, is Eotanford 963 in the bounds of Church Aston, apparently 'Eota's ford'. The unrecorded personal name ${ }^{*} \bar{E}$ ota would be the normal west midland form of West Saxon $\bar{Y} t a$. If $\bar{Y} t a$ has an ethnonymic function in the Hampshire names-if, for instance, it is a byname meaning 'the Jute'- then we should reckon with it also in Shropshire. That leaves only John of Worcester's Ytene. The association in the same text of provincia Jutarum with the New Forest makes it very likely that this is a genuine reference to Jutes; but, in the form in which it has been passed down, it is not a place-name. The chronicler may have taken it from an $\mathrm{OE}$ text in which it was part of a hypothetical *Ytenewald, but that is not evidence for its more general currency in spoken contexts.

\section{Discussion}

It is clear from the analysis above that identifying Seaxe-and ${ }^{*} \bar{E}$ ote-names is especially challenging. However, patterns of compounding shared with other group-name place-names may support the inclusion in our corpus of a considerable number of these names, even when the early forms allow for other interpretations. Determining the sense and significance of the ethnonyms within the corpus of place-names assembled above is not straightforward. What

115 JW vol. 3, s.a. 1100; Ekwall "Tribal Names," p. 132; Coates, Place-Names of Hampshire, p. 122.

116 JW vol. 3, s.a. 1099. Insley, "Meanware," p. 475; Yorke, "Jutes of Hampshire and Wight," pp. 90-91. 
follows is an assessment of the possible significances of the more securely identified group-name place-names.

Many - if not all—of the place-names under discussion have been interpreted by scholars as containing references to distinctive minority groups, communities who were notably different in some way from their surrounding populations. It is this assumption that lies behind Ekwall's statement, "[i]t is $a$ priori obvious that places were not generally named from the tribe or nation in whose territory they are found."117 These names are usually interpreted as having arisen in the speech of surrounding populations, rather than as selfidentifying labels.

Even within one subset of our corpus-the Engle/Englar names, for example-the cultural and/or linguistic identity that made the referents distinct was unlikely to have been uniform. As was noted above, the group-names could have varying referents in the documentary record. The same variation in application might be observable in the place-names, and indeed place-name usage might depart significantly from that of written documents, whose contexts of production were very different. What, if anything, can be said about the ways in which these group-names were used in place-names?

For the English-language Engle-names, it is usually the more specific-more Bedan-sense of 'Angle' that is thought to be active. A.H. Smith summarised, "Outside East England, the E[ast] Midl[ands], and the N[orth] C[ountry], the word refers in $\mathrm{p}$ [lace]n[ame]s. to an isolated settlement or group of Angles."118 They tend to be seen as evidence of migration from further north or east in England.

Englebourne in Devon can readily be interpreted as one such 'Anglian' name. Ekwall—and Smith—writing in the 1950s, saw the Engle here as a distinctive minority group within Wessex. ${ }^{119}$ An English-language name must of course have been formed at some point after the West Saxon expansion into this area in the late 7 th to early 8th centuries. Englebourne's genesis was probably considerably later than the initial movements westwards, as the scant evidence there is suggests that, in Devon, Old English speakers initially adopted Brittonic place-names, which were only later replaced by Old English formations. ${ }^{120}$ This replacement was largely complete by the time of the Domesday Survey, at least for the types of settlement-name contained therein, but it is

\footnotetext{
117 Ekwall, "Tribal Names," p. 130.

118 Smith, Elements, part 1, p. 153 .

11 Ekwall, "Tribal Names," pp. 138-9; Smith, Elements, part 1, p. 153.

120 Duncan Probert, "Mapping Early Medieval Language Change in South-West England," in Britons in Anglo-Saxon England, ed. Nick Higham (Woodbridge, 2007), pp. 231-44, at p. 233 .
} 
evidenced in texts from the 9th century. ${ }^{121}$ And by the late 9th century Englebourne was, if not exactly West Saxon heartland, very nearly so-a number of nearby estates were bequeathed by King Alfred, in his will, to members of his family. ${ }^{122}$ Angles may well have been notable in such a context. Back in 1931, however, Gover, Mawer, and Stenton, the English Place-Name Society (EPNS) editors for Devon offered a rather different reading. They suggested that Englebourne "may mean 'bourne or stream of the English', possibly because at one time it formed the boundary between the British and the invading AngloSaxons."123 The notion of a fixed boundary between Britons and Anglo-Saxons is of course problematic from a 21st-century perspective, ${ }^{124}$ but it is perhaps worth exploring the idea that the name referred in some way to the (notional) extent of English control. At first glance, Gover, Mawer, and Stenton's suggestion, with its reference to "invading Anglo-Saxons," seems to rest on the assumption that the name was formed at the time they were moving westwards into this area. The name is perhaps unlikely to date from this period for the reasons mentioned above, and the use of Engle at this early date is also problematic. If the (English) name had been formed during a period of West Saxon expansion into Brittonic-speaking regions, it would of course have to have been self-identification on the part of the English speakers. Self-identification as Engle, rather than Seaxe, at a time earlier than that for which we have evidence that Engle could denote English speakers regardless of regional origin is improbable. Gover, Mawer, and Stenton may, though, have envisaged a later context for the formation of Englebourne, and it is possible to imagine it arising, with this 'boundary' sense, as a name which preserved — or invented-a folk-memory of an earlier border between English and British, at a time after Engle had come to mean English speakers. If English-language names in this part of the world originated, on the whole, in the gth and later centuries, then this is at least a possibility.

Englefield in Berkshire is the other Engle-name for which the "contrasting" population is thought to be West Saxon. ${ }^{125}$ Berkshire was contested territory,

\footnotetext{
121 Probert, "Mapping," p. 233.

122 Simon Keynes and Michael Lapidge, Alfred the Great (Harmondsworth, 1983), pp. 173-78, esp. map 5 .

123 The stream referred to is now the River Harbourne, a tributary of the Dart. Gover, Mawer, Stenton, Place-Names of Devon, pp. 325-26.

124 Both for what it implies about British/Anglo-Saxon relations and because medieval borders were probably zones rather than linear features. See, for example, Probert, "Mapping," p. 232, and the references in Fiona Edmonds, "The Expansion of the Kingdom of Strathclyde," EME 23 (2015), 43-66, at p. 53, nn. 44, 45.

125 DEPN, p. 167;CDEPN, p. 216.
} 
and came under Mercian rule in the late 8th and early 9th centuries. Margaret Gelling pointed out that the phonology of the county's place-names was not obviously affected by these periods of Mercian rule-the names owe their forms to the West Saxon dialect. This suggested to her that Mercian overlordship was just that, and "did not affect the composition of its population," and that "[ $t$ ]he Angles of Englefield [...] would not have been mentioned in a placename if they had not been exceptional. ${ }^{126}$ Citing Englefield as evidence of the lack of any settlement concomitant with Mercian dominion has the effect, probably unintended, of identifying the name's Engle with Mercia. Engle did not necessarily refer to settlers from "core" Mercian territory. Their linguistic or cultural distinctiveness may have had its origins well outside that territorythat Engle could refer in place-names to a non-Mercian Anglian identity may be suggested by its use in Engleton in Staffordshire. ${ }^{127}$ Englefield's Engle could have been Middle or East Angles.

A memorializing function for Englefield was suggested by Ekwall, who offered a "mere guess" that "the name commemorates an early battle between Angles and Saxons," ${ }^{\prime 28}$ and by Andrew Reynolds, who suggested that the name may have been a deliberate bestowal by the West Saxons on the place where in 871 Æthelwulf, ealdorman of Berkshire, defeated two jarls of the Great Viking Army. ${ }^{129}$ Reynolds' contention is that the term Engle here reflects a conscious use of language which stresses English unity. This has most commonly been detected in the use of Angelcynn, from the late gth century and primarily in texts associated with Alfred's court, to refer to both Mercians and West Saxons as a unified people. ${ }^{130}$ These arguments rest, at least in part, on feld here having the sense of battle-field, and this is indeed one of the word's senses. ${ }^{131}$ However, it seems unlikely to have been the one at work in Englefield when we look at

126 Gelling, Place-Names of Berkshire, p. 839 .

127 See below, pp. 141-42; Ekwall, "Tribal Names," p. 139.

128 Ekwall, "Tribal Names," p. 139.

129 Andrew Reynolds, "Archaeological Correlates for Anglo-Saxon Military Activity in Comparative Perspective," in Landscapes of Defence in Early Medieval Europe, ed. John Baker, Stuart Brookes, and Andrew Reynolds (Turnhout, 2013), pp. 1-38, at pp. 26-27.

130 Patrick Wormald, "Bede, the Bretwaldas and the Origins of the Gens Anglorum," in Ideal and Reality in Frankish and Anglo-Saxon Society: Studies Presented to J.M. Wallace-Hadrill, ed. Patrick Wormald, Donald Bullough and Roger Collins (Oxford, 1983), pp. 99-129; Patrick Wormald, "The Venerable Bede and the 'Church of the English', in The English Religious Tradition and the Genius of Anglicanism, ed. G. Rowell (Oxford, 1992), pp. 13-32; Sarah Foot, "The Making of Angelcynn: English Identity before the Norman Conquest," TRHS 6th ser. 6 (1996), 25-49. For these issues, see also Courtnay Konshuh, "Constructing Early Anglo-Saxon Identity in the Anglo-Saxon Chronicles," below, pp. 154-79. However, cf. George Molyneaux, “Angli and Saxones in Æthelweard's Chronicle," EME 25:2 (2017), 208-23.

131 See the detailed discussion of feld in Gelling and Cole, Landscape, pp. 269-78. 


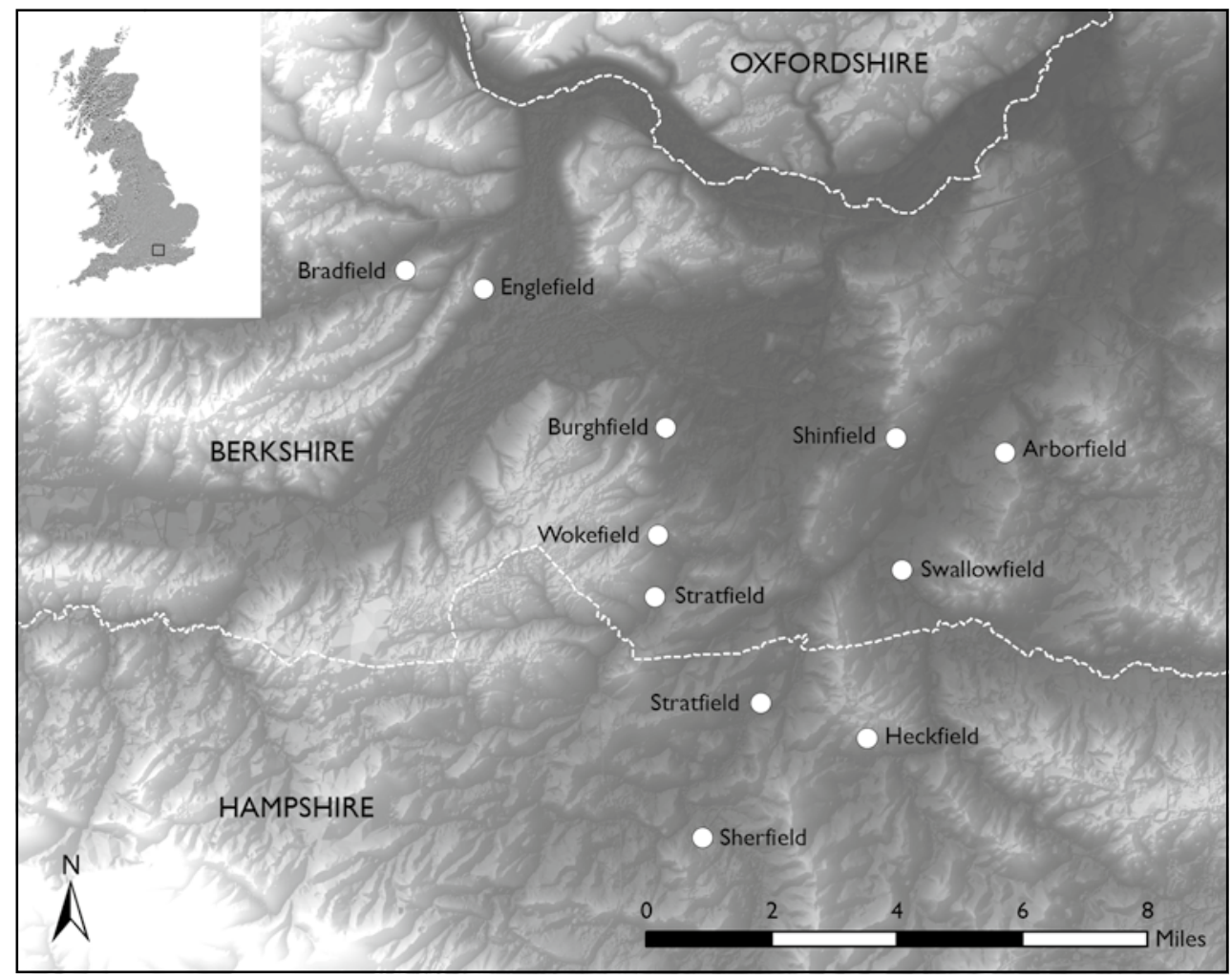

FIGURE 6.1 Feld-names in Berkshire and Hampshire MAP PRODUCED BY RICHARD JONES

the name in context. It is one of a swathe of feld-names found in West Berkshire and neighbouring Hampshire (Fig. 6.1). ${ }^{132}$ Feld here seems to have been used in contrast to forested land just to the east. Stripped of commemorative function, it is difficult to understand how a general sense of Engle 'English' would work in this particular location. A more specific 'Anglian' sense seems more likely, especially as feld is relatively common in the earliest attested place-names, and may belong to a fairly early stratum here rather than to the late ninth century (or later). ${ }^{133}$

Engleton in Staffordshire is situated, as Ekwall observed, in "old Anglian territory;" he therefore saw the names as having arisen at some point after Staffordshire's identity had become distinctively Mercian. ${ }^{134}$ For Ekwall, these

132 In Berkshire: Arborfield, Bradfield, Burghfield, Shinfield, Stratfield, Swallowfield, Wokefield; in Hampshire: Heckfield, Sherfield, Stratfield (Gelling and Cole, Landscape, p. 272).

133 Gelling and Cole, Landscape, p. 272.

134 Ekwall, "Tribal Names," p. 139. See also Smith, Elements, part 1, p. 153. 
Engle were incomers from further east, Middle or East Angles, defined against - and presumably by — a surrounding population whose primary identity was at that point not "Anglian." This population need not necessarily have identified as Mercian, of course; more local identities may have been at work. More recently David Horovitz has suggested that this area was "mainly British" at the point at which the name came into existence, noting that the British-OE hybrid name Brewood (Brit. briga 'hill', OE wudu 'wood') is less than $2 \mathrm{~km}$ away. ${ }^{135}$ While the name Brewood is not necessarily in itself compelling evidence for the late survival of a British-speaking community, ${ }^{136}$ Engleton is certainly far enough west to imagine significant continuity in population in this area from pre-English times through to the later Anglo-Saxon period; retention of British speech was not necessarily part of that continuity. Ekwall and Horovitz envisage significantly different social and linguistic environments and processes of naming. The first is an entirely English cultural environment, with the place-name arising descriptively in speech. The second is a situation of cultural contact, and possibly one where the place-name was imposed by the settlement's inhabitants, an example of self-identification. It was noted above (pp. 119, 130-31) that many place-names of the type ethnonym + tün occur in the Danelaw and suit a context after the Scandinavian settlements. This adds further uncertainty to any interpretation of Engleton. It could suggest a later context for the name, which in turn would count against a linguistically or "culturally" British environment.

Inglewood (Forest) in Cumberland is perhaps the only Engle-name for which we can suggest with some confidence a particular context of production. There seems to be general agreement that here we have English or Angles defined against a population which was in some sense British. Ekwall suggests that these Engle were "in Welsh territory," Smith that they were "amongst the Cumbrian Britons," and the EPNS editors and Watts plump for the Britons of Strathclyde. ${ }^{137}$ The area so named would have been part of the kingdom of Northumbria before its collapse in 867, and though enclaves of Brittonic speakers may have survived Northumbrian rule these were unlikely to have been land-owners. ${ }^{138} \mathrm{~A}$ significant Brittonic-speaking population re-emerged only in the late 9th or 1oth century, with the southwards expansion of the

\footnotetext{
135 Horovitz, Place-Names of Staffordshire, p. 248.

136 A reflex of *briga may have been adopted by English speakers into their onomasticon; Padel, "Brittonic Place-Names," pp. 24-25.

137 A.M. Armstrong, et al., The Place-Names of Cumberland, 3 vols (Cambridge, 1950-52), p. 38; DEPN, p. 265; Smith, Elements, part 1, p. 153; CDEPN, p. 331.

138 Edmonds, “The Expansion," p. 49.
} 
kingdom of Strathclyde. ${ }^{139}$ Inglewood, between Carlisle and Penrith, formed part of the southernmost extent of this kingdom, "an inland border zone that comprised Inglewood Forest and the Eamont/Penrith area."140 Given that the population here and further north and west comprised speakers of several different languages - English, Scandinavian, and Goidelic, as well as Brittonicit seems more likely that Inglewood is a name referring to political rather than linguistic identity, one that was given in recognition of the fact that this area was where British political control petered out. This is perhaps not a case of a 'minority population' name, but one used with a particular political significance to mark a borderland area.

It is perhaps of interest, then, that when we look at the distribution of the more secure OE Engle-names-leaving, for a moment, Ing Lane-they are all located in what might be termed borderland areas, where one set of historic identities or allegiances intersected with another (Fig. 6.2). Englebourne lies within Anglo-Saxon territory but not far from areas where Brittonic speech endured; Engleton, in the west midlands, lies in an area in which British identities, cultural and linguistic likely lasted longer than areas not much further east; and the name Inglewood seems to have arisen in the context of British territorial expansion into English speaking (or linguistically mixed) areas. Englefield lies within territory claimed at various points by Mercia and Wessex. There is perhaps something more to these names than their referring 'observationally' to minority groups, then. Inglewood looks like a reference to the limits of political power, and, while the other names may not have this precise function, it may be that ethnic identifiers arose in historically contested areas, even if that contest was a relatively distant memory at the point at which the name came into existence.

A distribution map of OE Seaxe-names is strikingly different from that of Engle-names, both because of the markedly greater number of possible instances (Fig. 6.3), and because of the number of names located within Scandinavian-influenced areas. Some of these names may fit a 'borderland' interpretation.

Seaxana meare refers directly to a boundary, of course, and is possibly therefore a special case. The estate of Flodhammas, whose southern border it comprised, lay within Walland Marsh and the parishes of Brookland, Brenzett, and Fairfield, all of which abut Kent's boundary with Sussex. Seaxana here may be elliptical, or it may represent an everyday "vernacular" reference to South

139 Edmonds, "The Expansion"; Edmonds's adaptation of the traditional interpretation is compelling, but for alternative explanations see the references in her footnotes 5, 7.

140 Edmonds, "The Expansion," p. 55. 


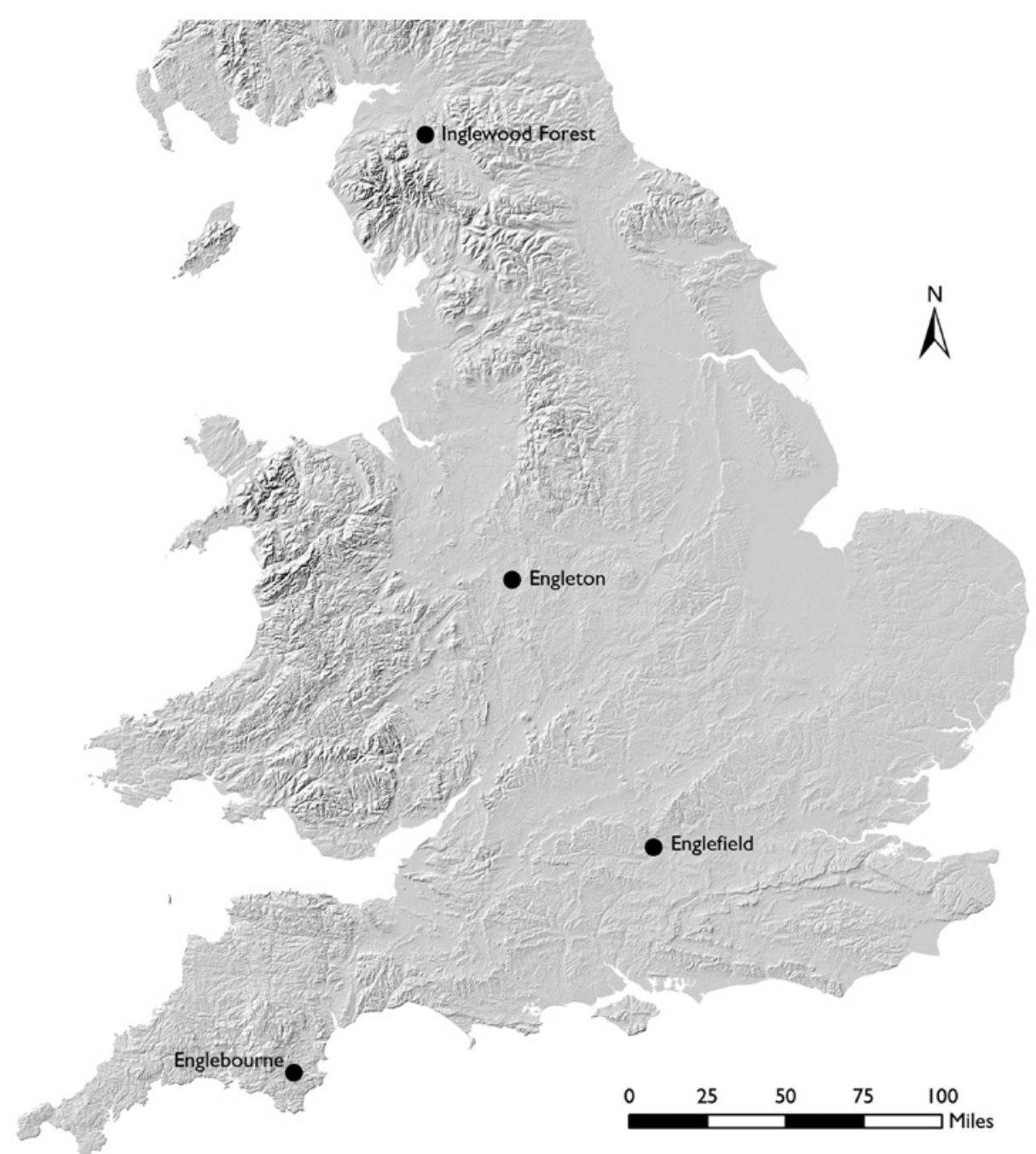

FIGURE 6.2 OE Engle-names

MAP PRODUCED BY RICHARD JONES

Saxons. The more specific Supsaxa lond (see above, p. 115) lay less than 10 miles to the east, and may represent a detached part of South Saxon territory. It is perhaps of interest that we have a "full" form of the group-name in such a context, with what may be a direct reference to land-holding within Kentish territory by a political unity.

Sessacott and Saxworthy are located on the western periphery of AngloSaxon England, close to the Anglo-Cornish border, and their motivation is a 


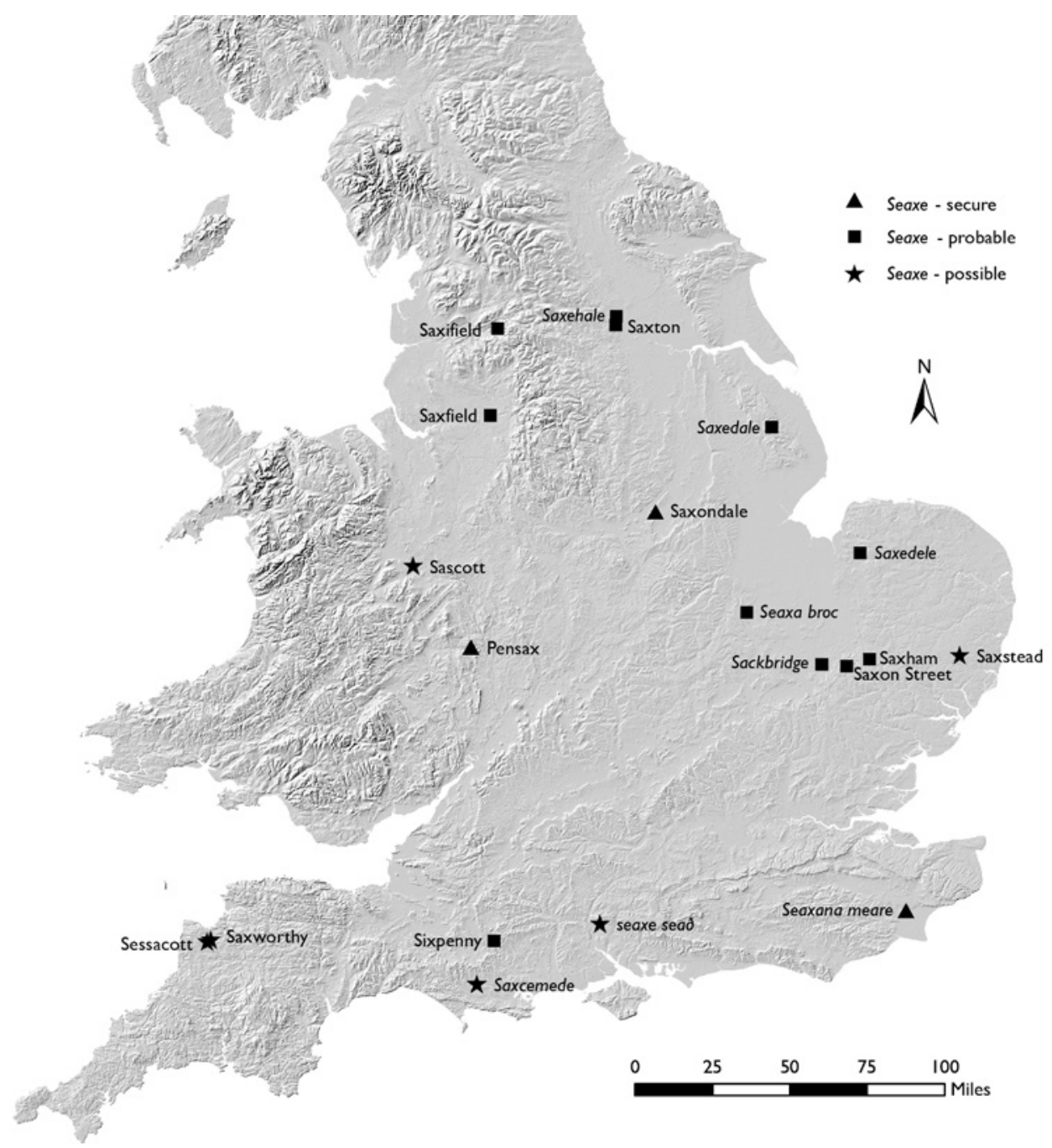

FIGURE 6.3 Seaxe distribution map

MAP PRODUCED BY RICHARD JONES

matter of some curiosity, if, as discussed above, they contain the personal or by-name Seaxa rather than the ethnonym Seaxe. It may be that the social conditions of the border region gave rise more readily to use of the ethnonym in given names or as a byname. The use of OE Seaxa 'the Saxon' as a by-name in Sascott, however, on the edge of supposedly Anglian Mercia, is harder to interpret in this way, unless we reckon with some sort of semantic influence 
from Brittonic *Saðso-, whose referents were English rather than specifically Saxon. It is not difficult to imagine such influence on the English spoken in this part of the west midlands, whether that of "original" Germanic-speakers or of those who had learned it under political exigency. The other west midland name in the corpus, Pensax, a Brittonic place-name, is very likely to contain the ethnonym, whether in reference to an individual Saxon or a community of Saxons. In Della Hooke's view, the name arose because "a group of Anglo-Saxon settlers were sufficiently distinctive in north-west Worcestershire to give their name ... to the estate of Pensax ... in the woodland beyond Wyre."141 Whether this distinctive group was an isolated community surrounded by Brittonic speakers, or dwellers in the borderland at the limits of Anglo-Saxon expansion, the name seems likely to have arisen at an early stage, when Anglo-Saxon culture or Old English language were distinctively rare in this part of Worcestershire. In Gelling's judgment, Old English had come to dominate even in districts much further west by the end of the 9th century. ${ }^{142}$ An early date was also proposed by Kenneth Jackson, on phonological grounds, although Alan James demurs. ${ }^{143}$ Full discussion of this name belongs with a detailed analysis of comparable Brittonic material, and is beyond the scope of this chapter. Whether Sixpenny should be treated separately is moot. Its location is much less clearly culturally liminal, except in the very earliest of Anglo-Saxon contextsAnderson posits "an ancient Saxon boundary" in explaining the name's motivation. ${ }^{144}$

Another group of Seaxe names might be considered to have arisen in a border environment: Saxon Street, Saxham, and Sackbridge. Ekwall considered them remnants of an early Saxon migration to this otherwise predominantly Anglian area, ${ }^{145}$ but all three are located about 10 miles north of the modern county boundary of Essex. If that is a good approximation of the extent of East Saxon territory in the Anglo-Saxon period, ${ }^{146}$ then it is not inconceivable that control of parts of southern Cambridgeshire and Suffolk was contested by the

141 Della Hooke, The Anglo-Saxon Landscape: The Kingdom of the Hwicce (Manchester 1985), p. 164.

142 Margaret Gelling, The West Midlands in the Early Middle Ages (Leicester, 1992), pp. 70-71.

143 Jackson, Language and History, pp. 539-40; Alan G. James, "A Cumbric Diaspora?" in A Commodity of Good Names: Essays in Honour of Margaret Gelling, ed. O.J. Padel and David N. Parsons (Donington, 2008), pp. 187-203, at p. 198.

144 Anderson, South-Western Counties, p. 141.

145 Ekwall, "Tribal Names," p. 137.

146 Barbara Yorke, "The Kingdom of the East Saxons," ASE 14 (1985), 1-36, at pp. 27-31; Kings and Kingdoms of Early Anglo-Saxon England (London, 1990), pp. 46-47. 
East Saxons at various times, or that East Saxons migrated into these nearby areas after the initial settlement period. It is harder to make such an argument for Saxstead, around 20 miles north of the boundary, but in any case the personal names is probably more likely than the ethnonym here. ${ }^{147}$

The remaining OE Seaxe-names are harder to read as expressions of border dynamics, and the conventional interpretation, as isolated communities of Saxons in areas whose identities Bede classed as collectively Anglian, may be preferable. Dodgson considered Saxfield to commemorate "a settlement of Saxons among the Anglian population of north-east $\mathrm{Ch}[$ eshire];"148 Gover, Mawer and Stenton considered Saxondale in Nottinghamshire to record "some isolated Saxon settlement in this Anglian territory."149 Gover et al. went further, in fact, and suggested that the presence of a Saxon population might account for use of OE denu, otherwise rare in Nottinghamshire; this seems not to be entirely supported by more detailed analysis of that element, ${ }^{150}$ but the recurrence of generics referring to valleys and nooks, in Saxondale, Saxehale, and the two instances of Saxedale, is worthy of note. Parallels can be found in the place-name Walden (Essex, Hertfordshire), from OE Wala-denu 'valley of the Britons', and Eadens in Hampshire (above, p. 136) might also be compared. ${ }^{151}$ The historical context for these isolated communities is impossible to reconstruct, since place-names are generally their sole evidence and we cannot date their coining very precisely. Does a name such as Saxfield, near the border of Lancashire and Cheshire, tell us that Saxons and Angles were both present in that region in the early to mid Anglo-Saxon period, or that a group of Saxons migrated to this otherwise Anglian land at a later date? The name Exton shows that movements of this kind could take place and be recorded in place-names after the establishment of a distinctively East Saxon identity. In an otherwise apparently non-Saxon region, OE Seaxe might sometimes have been short for $\bar{E}$ ast, Süð or West Seaxe, as may have been the case in Seaxana meare on the border with Kent. On the other hand, if many of the names originated early on, they presuppose a much more mixed settlement of Angles and Saxons that belies Bede's later rationalization.

\footnotetext{
147 Although it is worth noting the suggestion that Sutton Hoo once marked the border of East Saxon territory, see Michael Parker Pearson, Robert van de Noort and Alex Woolf, "Three Men and a Boat: Sutton Hoo and the East Saxon Kingdom," ASE 22 (1993), 27-50.

148 Dodgson, Place-Names of Cheshire, part 1, p. 236.

149 Gover, Mawer and Stenton, Place-Names of Nottinghamshire, p. 241.

150 Gelling and Cole, Landscape, p. 113 .

151 Reaney, Place-Names of Essex, p. 537; J.E.B. Gover, Allen Mawer, and F.M. Stenton, The Place-Names of Hertfordshire (Cambridge, 1938), pp. 22-23.
} 
The exceptions here are the Jutes, whose name seems to be confined at most to one Jutish area only, and is not apparently found elsewhere. This may be because they have not been looked for beyond their Bedan districts; or because the Jutish identity was subsumed by a West Saxon one early on. John Insley contends that " $[t]$ he separate Jutish identity [of parts of Hampshire and of the Isle of Wight] lasted for a considerable time."152 This rests on seeing Asser's reference to Alfred's maternal grandfather, Oslac, as de Gothis et Iutis 'from the Goths and Jutes' as reflecting a late gth-century consciousness of Jutish origins in those regions, to which Oslac's family belonged. ${ }^{153}$ It is hard to know, however, whether this is anything more than a reflection of learned tradition or acquaintance with Bede. The scarcity of ${ }^{*} \bar{E}$ ote-names does not especially weigh in favour of the Hampshire/Wight population continuing to identify with the Jutes for an extended period of time. If this scarcity is indeed a result of that identity being subsumed by a West Saxon one, it might support an interpretation of many Seaxe- and Engle-names as having arisen at a relatively late date; they arose, perhaps, at a time when those identities were more clearly geographically defined. A late interpretation may also more easily explain those Engle- and Seaxe-names located in borderlands, whose semantic value required an understanding that there were Anglian or Saxon polities.

Chronology is less of a problem for those names which show Scandinavian influence, and which therefore must date from the late gth century or later. They are best discussed together, particularly as eight of them are by-names. Ethnonym + bý is recurrent in Danelaw areas of England: the generic is found with specifics referring to Britons (Bretar), Flemings (Flcemingjar), Frisians (Frísir), Irish/Goidelic speakers (Írar), Scandinavians (Danir and Norðmenn), as well as Englar and Saksar. For this reason, the Saxby-names are very likely to contain the ethnonym, despite there formally being other possibilities. Scholars who have preferred an ethnonym interpretation have argued that the Saxbys, like the Inglebys, refer to English-speaking communities. Gillian FellowsJensen offers two possibilities:

the Danes must either have been able to distinguish between the Angles and the Saxons or have used the two national terms synonymously. The latter alternative seems the more likely. ${ }^{154}$

\footnotetext{
$15^{2}$ Insley, "Meanware," p. 474.

153 Asser, chapter 2.

154 Fellows Jensen, Scandinavian Settlement Names in the East Midlands, p. 66.
} 
Barrie Cox adds that, "by the date of such a name's formation, the Danes were unlikely to have been able to distinguish between Angles and Saxons." ${ }^{155}$ The traditional argument holds that Saxby-and Ingleby-names referred to English-speaking communities in areas dominated by Scandinavian speakers, and indeed they certainly occur within areas whose place-names are good evidence for heavy Scandinavian linguistic influence. However, given that the element by compounds elsewhere with ethnonyms referring to peoples of the European mainland, the possibility should be borne in mind that the Saxbynames in fact refer not to (Anglo-)Saxons but to 'Old' Saxons, from Saxony. OE Seaxe refers sometimes to Continental Saxons; in Scandinavian contexts, ON Saksar refers only to Continental Saxons. If the Saxby-names were formed by Scandinavian speakers, as seems likely, ${ }^{156}$ why would Saksar have been the term chosen to denote English speakers? There is no Scandinavian textual evidence to suggest that it was used with this sense, and, had Scandinavian communities in the Danelaw learned the vocabulary for English speakers from their Anglo-Saxon neighbours, we may wonder why these neighbours would have self-identified as Seaxe. If we allow that Flemings and Frisians appear in English place-names, ${ }^{157}$ then we must allow that Continental Saxons may too. It is worth noting that one of the Lincolnshire Saxbys is just over a mile from a lost Frísa-bý site, ${ }^{158}$ and Saxby in Leicestershire is approximately 8 miles from Frisby on the Wreake, one of three Frísa-býs in that county. ${ }^{159}$ If the Saxbys do indeed refer to Continental Saxons, this makes better sense of a situation in which both Englar and Saksar bý-names are found in the east midlands at no great distance apart, in one case fewer than 10 miles apart (Fig. 6.4).

Considering the names within the broader onomastic context might also cast light on whether these names did indeed refer to minority communities surrounded by one dominant group. The recurrent names in *Engla-býwhich can readily be interpreted as Old Norse formations ${ }^{160}$ — are, for example, usually identified by scholars as groups of English speakers surrounded by

155 Cox, Place-Names of Leicestershire, part 2, p. 135; see also CDEPN, p. 529.

${ }_{15} 6$ For bý-names as evidence of Scandinavian linguistic communities, see Abrams and Parsons, "Place-Names and the History of Scandinavian Settlement in England," esp. pp. 394-400.

157 Flcemingjar in Flimby (Flemyngeby 1171-5): Armstrong, et al., The Place-Names of Cumberland, p. 286.

158 West Firsby; Cameron, Place-Names of Lincolnshire, part 6, p. 154.

159 Cox, Place-Names of Leicestershire, part 3, p. 80; for the other two see part 4, p. 58, and part 6, p. 141.

16o See above, pp. 119-20. 


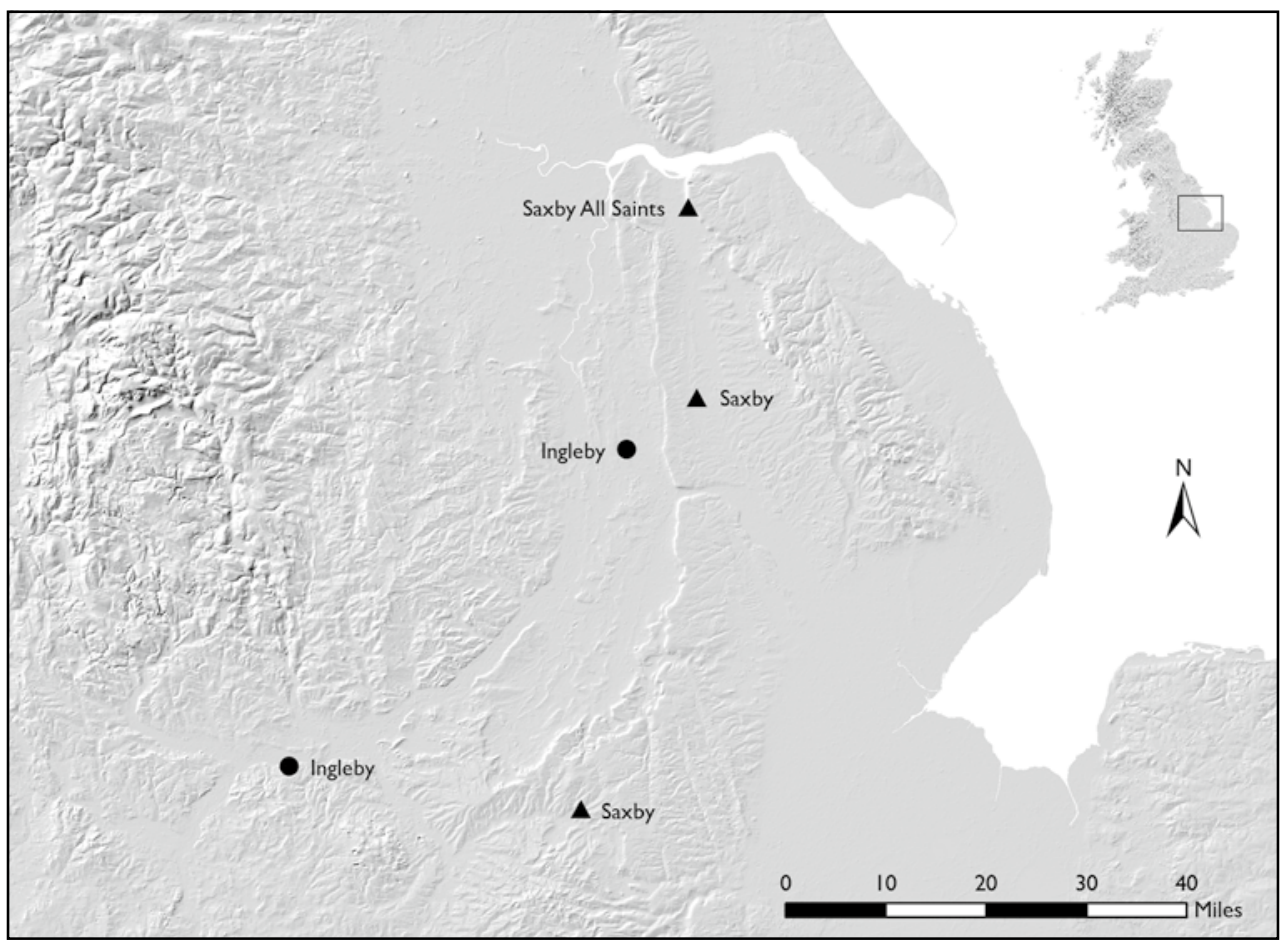

FIGURE 6.4 East midlands names

MAP PRODUCED BY RICHARD JONES

Scandinavians. ${ }^{161}$ Ethnonym + bý-names tend to occur in clusters, however, which rather suggests that these names were characteristic of areas whose populations were thoroughly mixed and ethnically dynamic, ${ }^{162}$ but where Old Norse was the dominant language in the toponymicon at the time that these names arose. Fig. 6.5 shows one such cluster in the North Riding of Yorkshire.

Less can be said about the remaining two possible Saksar-names, the lost Sash Gate, in Owersby parish, Lincolnshire, and Saxthorpe in Norfolk. The personal name Saxi is a formal possibility in both of these, and is accepted by most scholars as the specific of Saxthorpe. As there are just two other possible

161 In addition to the references given above for each name, see also Cameron, English Place Names, p. 77; Gillian Fellows Jensen, Scandinavian Settlement Names in Yorkshire (Copenhagen, 1972), pp. 13, 30-31; Fellows Jensen, Scandinavian Settlement Names in the East Midlands, pp. 19-20, 55 .

162 Carroll, "Identifying Migrants." 


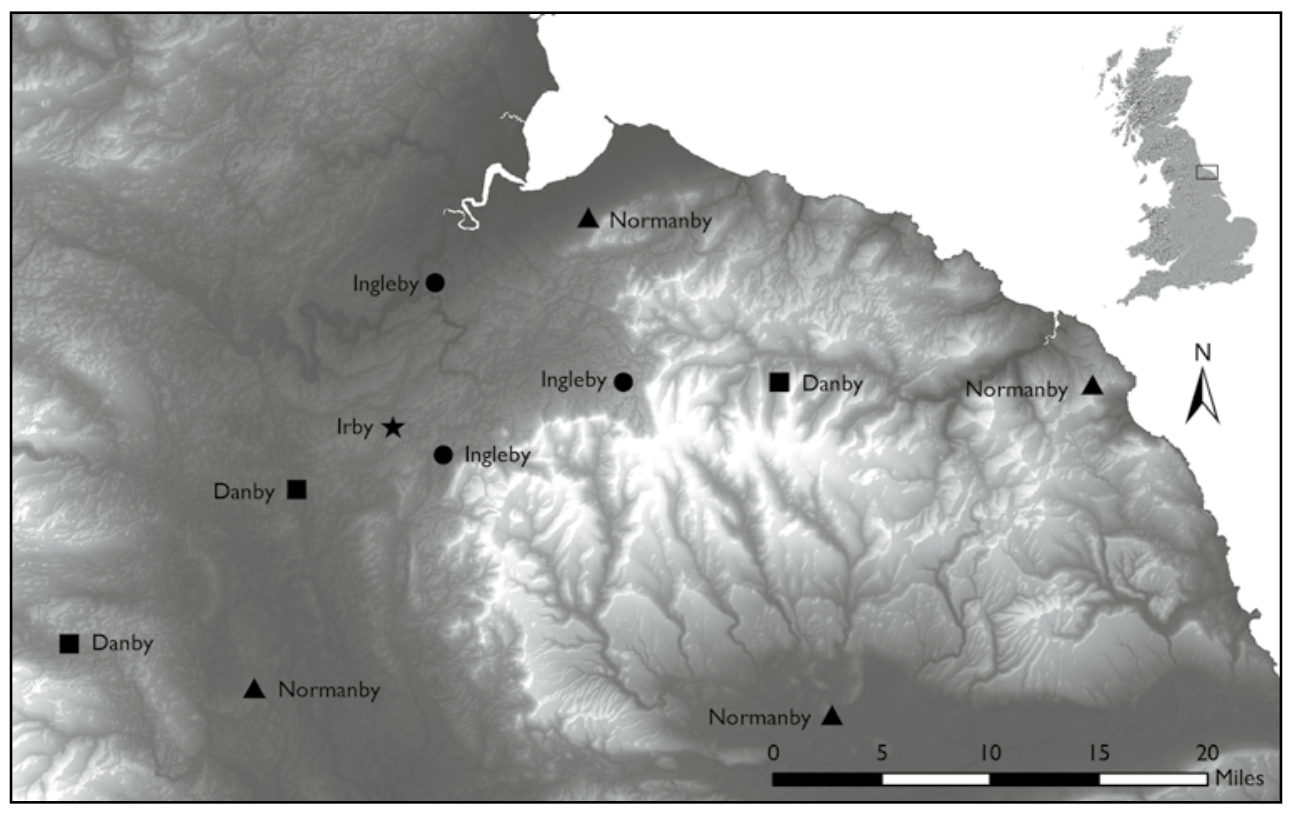

FIGURE 6.5 North Riding cluster

MAP PRODUCED BY RICHARD JONES

ethnonym names in ON porp but very many personal names, ${ }^{163}$ this is probably the safest assumption. Sash Gate, on the other hand, sits with ten or more other names comprising ethnonym + ON gata, plus several additional names comprising ethnonym + routeway. For Sash Gate, as for the Saxby-names, it has been argued that the Saksar were Anglo-Saxons. ${ }^{164}$ However, it is possible again to point to instances in which gata compounds with specifics referring to Continental European peoples: there is a Flcemingja-gata 'road of the Flemings' in Beverley, as well as recurrent instances of Norðmanna- and Dana-gata. A possible reference to Continental Saxons must at least be considered. What the relationship between the Saxons (of whatever origin) and the road might be is not entirely clear. There are three surviving instances of ethnonym + gata: Jubbergate in York (Bretar), Flemingate in Beverley, and Deansgate (Danir) in Grimsby. These are also the earliest attested of the ethnonym + gata compounds, all appearing in 12th-century documents. The roads so-named are

\footnotetext{
163 See, for example, the numbers in Fellows Jensen, Scandinavian Settlement Names in the East Midlands, pp. 92-101, and see above, p. 134.

164 Cameron, Place-Names of Lincolnshire, part 3, p. 88.
} 
within substantial settlements: Ekwall suggested that Britons were Jubbergate's main inhabitants, and Smith that Flemingate was occupied by Flemish traders. ${ }^{165}$ Occupation or trading sites are certainly possible motivations for such names, and may lie also behind Ing Lane (if the name does indeed contain Engle), which Ekwall saw as "the result of an early Anglian immigration into London."166 Use of the road in question is an alternative explanation, as in Alan James's assessment of the two $\operatorname{Bret}(t) a$-strēet names in the north west, which "presumably refer to Cumbrian drovers or traders."167 Ekwall explained these names as referring to their perceived builders, but that rested on their having been applied, as he thought, to Roman roads. ${ }^{168}$ Such an explanation seems unlikely to apply to Sash Gate, which lay within the Lincolnshire village of Owersby, or indeed to any of the gata names.

\section{Conclusions}

In considering the material set out in this essay, we are inevitably indebted to and constrained by Bede's ethnographical framework. In many cases, we can only judge the motivation of an Engle, Seaxe or Éote place-name against his parameters. Yet the reality of early Anglo-Saxon identities must have been ethnically and geographically more complex: ethnically complex because of participation in the settlement of England by other Germanic 'tribes' not mentioned by Bede in this passage; 169 geographically complex because it is hard to imagine an uncontrolled, early medieval mass migration with such a neat outcome. Barbara Yorke's cautionary observation, when assessing Bede's description of the languages of Britain, is just as valid here:

... Bede seems to show awareness that the identity of Angles and Saxons (and presumably the Jutes), although partly the result of heavy migration from certain areas in the Germanic homelands, was also the product of a certain rationalization and regrouping of identity which occurred within Britain itself... ${ }^{170}$

\footnotetext{
165 Ekwall, "Tribal Names," p. 162; Smith, Place-Names of the East Riding, p. 195.

166 Ekwall, Street-Names, p. 123.

167 James, "Cumbric Diaspora?" p. 191.

168 Ekwall, "Tribal Names," p. 162.

169 Compare the tantalizing implications of HE v.9.

170 Barbara Yorke, "Political and Ethnic Identity: A Case Study of Anglo-Saxon Practice," in Social Identity in Early Medieval Britain, ed. William O. Frazer and Andrew Tyrrell (London, 200o), pp. 69-89, at p. 72 (referring to Bede, $H E$, I.1, v.9).
} 
With our material there is an additional complication, that of chronologywe can rarely date the coining of these place-names with any great precision. Even so, it is clear that a number of them post-date the Scandinavian settlement of northern and eastern England, another time of migrations to and within Britain. If some of the place-names discussed here arose during the $5^{\text {th }}$ and 6th centuries, or reflect patterns of settlement established at that time, other contexts should also be sought in explaining the full range of names. If we are aware that Bede's description of the settlement of Angles, Saxons and Jutes may be a rationalization of a very complex reality, we must also avoid simplification in explaining the toponymic afterlives of those 'tribes'. 